Review

\title{
A Critical Review of Demand Response Products as Resource for Ancillary Services: International Experience and Policy Recommendations
}

\author{
David Ribó-Pérez *D, Luis Larrosa-López, David Pecondón-Tricas and Manuel Alcázar-Ortega (D) \\ Institute for Energy Engineering, Universitat Politècnica de València Camí de Vera S/N, 46022 Valencia, Spain; \\ luis_larrosa@outlook.es (L.L.-L.); davidpecondon3a@gmail.com (D.P.-T.); malcazar@iie.upv.es (M.A.-O.) \\ * Correspondence: david.ribo@iie.upv.es
}

Citation: Ribó-Pérez, D.;

Larrosa-López, L.; Pecondón-Tricas,

D.; Alcázar-Ortega, M. A Critical

Review of Demand Response

Products as Resource for Ancillary

Services: International Experience

and Policy Recommendations.

Energies 2021, 14, 846. https://

doi.org/10.3390/en14040846

Academic Editor: Surender Salkuti

Received: 18 January 2021

Accepted: 1 February 2021

Published: 5 February 2021

Publisher's Note: MDPI stays neutral with regard to jurisdictional claims in published maps and institutional affiliations.

Copyright: (c) 2021 by the authors. Licensee MDPI, Basel, Switzerland. This article is an open access article distributed under the terms and conditions of the Creative Commons Attribution (CC BY) license (https:// creativecommons.org/licenses/by/ $4.0 /)$.
Abstract: Demand response is a key element of future power systems due to its capacity to defer grid investments, improve demand participation in the market, and absorb renewable energy source variations. In this regard, demand response can play an important role in delivering ancillary services to power systems. The lack of standardization and ancillary services programs prepared for traditional generators have blocked the participation of demand in these services. Nowadays, increasing needs to ensure the security of supply, renewable fluctuations, and information and communication technology advances are boosting the interest in demand response products to deliver ancillary services. While countries have had lengthy experience with these programs, others are starting from almost zero to develop these programs. To our knowledge, no analysis or standardized comparison exists of the different parameters and prices of demand response in ancillary services among different countries. Our study reviews more than 20 power systems around the world and their programs to classify them according to standard demand response parameters. At the end of the paper we discuss the main characteristics and prices that face demand response in ancillary services markets and a series of policy recommendations to policymakers to improve the deployment on demand participation in ancillary services.

Keywords: demand response; ancillary services; ENTSO-E; FERC; standardization; restoration reserves; operation reserves

\section{Introduction}

Power systems are under a period of rapid evolution. The integration of renewable energy sources (RES) is necessary to achieve the Climate Change objectives [1], but it requires new solutions and more flexible power systems to achieve it at a reasonable cost [2]. A decentralized and dynamic paradigm is replacing the old centralized and rigid one [3,4]. Now, operators use all kinds of flexible resources to preserve balance, ensure the security of supply, and improve the efficiency of the system. New flexibility resources as Demand Side Management (DSM) require operators and policymakers to work together to create the appropriate legal and economic framework [5] and to establish the terms of flexibility.

Demand Side Management (DSM) refers to planning, implementing, and monitoring the use of electricity to generate changes in the consumers' demand profile to adapt to different needs [6,7]. DSM solutions are a valuable tool to smooth demand peaks [8], avoid blackouts, reduce investments on the grid [9] and absorb fluctuations of Renewable Energy Sources (RES) power output [10]. Nevertheless, these uses were marginal since power systems treated consumers as passive agents without the capacity to modify their loads and relied on the flexibility of fossil generators [4]. But now, when flexibility needs arise due to RES variability $[2,11]$, thanks to the advances in Information and Communication 
Technologies (ICT), DSM counts as necessary infrastructure to fully participate in the system flexibility throughout Demand Response Products (DRP) [12,13].

Demand Response Products (DRP) are not new; many countries have used this kind of program to accommodate them through the years with satisfactory results. The use of Demand Response (DR) was mainly set to avoid extreme and rare events as system blackouts and severe grid conditions to reduce grid decay [14]. Nowadays, the advances in ICT shows that DR has greater reliability to provide flexible services to the system than conventional generators [15]. First, DR can have lower costs than other flexible resources and can provide economic profits to the system as a whole and the consumers that provide it [16-18]. Second, DR presents an on-site solution to enable efficient integration of Distributed Energy Resources (DERs) that activate new market agents and open new business opportunities [19-21]. Third, DR can provide cheap and reliable Ancillary Services (AS) that were exclusively provided by generators, and as well as other consumer-based solutions, can help to reduce market power [22].

However, regulatory barriers remain an issue for the participation of demand. Regulatory barriers relate to market designs that limit the participation of demand, forcing them to participate in markets designed for generators. For instance, imposing large minimum bidding capacities or long time maintenance requirements that make difficult or even impossible the participation of most consumers [21]. To overcome the lack of scale, aggregators are gaining increasing attention in many policy interventions [23,24]. Aggregation is the activity of grouping several consumers to perform as one entity to respond to the operator in the market. An aggregator is an organization that deals with markets, System Operators (SO), and consumers, acting as the intermediary party to exploit the valuable resources that consumers under a contract can provide [25].

Therefore, power systems around the world are developing new and more dynamic programs to increase the participation of demand as agents, known as Balance Service Providers (BSP), which act as Demand Response Providers (DRPV) in direct competition with other BSP of other flexibility resources in the Ancillary Services (AS) markets [26] that are now open to DR.

To our knowledge, no analysis or comparison exists of the different parameters and prices of DRP in AS among different countries. On this basis, this article aims to provide a reference point to policymakers and researchers that work with DRP in the AS markets around the world. The article provides an analysis of the different country programs under a framework of standardized parameters of both AS and DRP. Hence, this work outlines a methodology to compare different DRPs under a common language to analyze the benefits and drawbacks found in them, taking special attention to their main technical parameters and prices. Finally, some policy recommendations for new DRP are presented.

The rest of the paper is organized as follows. Section 2 presents the methodology used to analyze the different DRP for AS. Section 3 provides information on the DRPs of different power systems in the different continents. The discussion arises in Section 4, where a comparison between programs and prices appears. Finally, the main conclusions are stated in Section 5.

\section{Materials and Methods}

\subsection{Standards to Classify Operation Services}

Systems use different nomenclature for AS across the world. In some regions exist degrees of standardization created by Transmission System Operators (TSOs) from neighboring countries and regions. Two of the best-known are the European and the North American standards, developed by the European Network of Transmission System Operators for Electricity (ENTSO-E) and the Federal Energy Regulatory Commission (FERC), respectively. Figure 1 provides a summary of the described standards. 


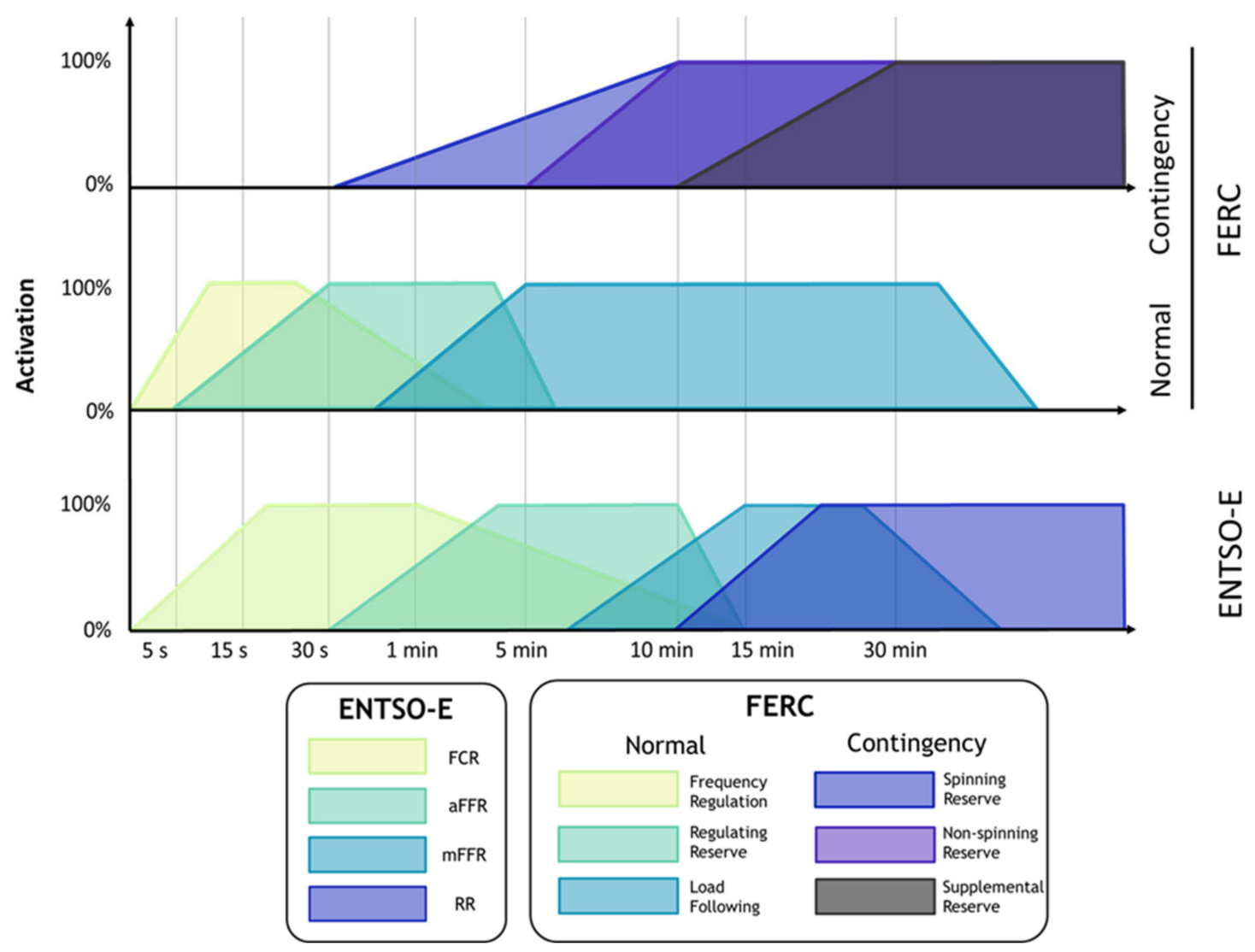

Figure 1. Comparison of European Network of Transmission System Operators for Electricity (ENTSO-E) and Federal Energy Regulatory Commission (FERC) nomenclature. FCR: frequency containment reserve; aFRR: automatic frequency restoration reserve; $\mathrm{mFRR}$ : manual frequency restoration reserve; RR: replacement reserve.

\section{ENTSO-E}

ENTSO-E stands for European Network of Transmission System Operators for Electricity. It is an organization that represents 42 TSOs from 35 European countries. Among many other functions, ENTSO-E coordinates most of the European TSOs and drafts common network codes for the countries. The nomenclature for the European AS is as follows [27]:

- Frequency Containment Reserve (FCR). This service aims to automatically stabilize the frequency after the occurrence of small and unpredictable imbalances. Actions within this type of service must start no later than $30 \mathrm{~s}$ from the imbalance, while the response covers up to $15 \mathrm{~min}$. Another common name for this service is Primary Reserve.

- Frequency Restoration Reserve (FRR). This service intends to respond to imbalances too long or too large to be solved by FCR. Therefore, its objective is to restore frequency and replace FCR. There are two versions of this service.

$\bigcirc \quad$ Automatic Frequency Restoration Reserve (aFRR). It works between $30 \mathrm{~s}$ and $15 \mathrm{~min}$ from the frequency deviation. Also known as Secondary Reserve.

- Manual Frequency Restoration Reserve (mFRR). It responds manually no later than $15 \mathrm{~min}$ from the imbalance. Also known as Tertiary Reserve.

- Replacement Reserve (RR). This service complements and/or replaces FRR when needed. It is a complementary reserve prepared for additional imbalances, which is manually activated no sooner than $15 \mathrm{~min}$ after the frequency deviation takes place.

FERC

FERC stands for Federal Energy Regulatory Commission. It is "an independent agency that regulates the interstate transmission of electricity, natural gas, and oil" in the United States [28]. Included among its many responsibilities is "to protect the reliability of the 
high voltage interstate transmission system through mandatory reliability standards". As part of this responsibility, the FERC has developed a nomenclature that classifies ancillary services over the United States and part of Canada. The services are divided into two groups according to the nature of the frequency disturbance.

- Operating Services for Normal Conditions These services are designed to deal with unpredictable frequency deviations mainly caused by inaccuracy on demand prediction and/or renewables production forecasts. There are three types of service within this group [29]:

$0 \quad$ Frequency Regulation. This service is based on Automatic Generation Control (AGC) and responds immediately to changes in frequency. It must be fully activated $10 \mathrm{~s}$ after the frequency disturbance started, and the activation normally lasts from a few seconds to several minutes.

- Regulating Reserve. AGC responds to the System Operator (SO) requests to bring back frequency or interchange programs to target. It must respond between $4 \mathrm{~s}$ and $1 \mathrm{~min}$ and lasts several minutes.

$\bigcirc \quad$ Load Following. This service bridges between regulation and intraday energy markets. It is like the Regulating Reserve but with slower starts and longer activity periods. It must respond between 5 and $10 \mathrm{~min}$, while the activation can last from $10 \mathrm{~min}$ to a few hours.

- Operating Services for Contingency Conditions These services provide a reserve to face a contingency event (predicted or not) and keep frequency on its normal value. At the same time, they replace other activated reserves so that the system returns to the same level of balance before contingency. There are three types of service:

- Spinning Reserve. It is defined as unloaded generation synchronized to the grid (rotating mass) that can be activated in case there is a frequency deviation caused by a contingency. The definition includes non-synchronized capacity that, by its technical traits, can be connected and activated as quickly as conventional Spinning Reserves. This service activates in less than $10 \mathrm{~min}$ from the contingency (normally much faster) and lasts up to $2 \mathrm{~h}$.

- Non-spinning Reserve. This resource has the same target as Spinning Reserve, but it includes offline resources that can connect and be fully active within 10 min and work for up to $2 \mathrm{~h}$.

- Replacement or Supplemental Reserve. This service acts to restore Spinning and Non-Spinning reserves to the status they had before the contingency. The service must be active $30 \mathrm{~min}$ after the contingency.

\subsection{Ancillary Services Parameters}

Table 1 describes the most important parameters that characterize a general AS defined in [25], which Figure 2 summarises. These listed parameters consider times, power requested, and characteristics as the type of activation.

\subsection{Demand Response parameters}

The most significant parameters that characterize a general DR product are described in Table 2. Technical requirements are also represented in Figure 3. 
Table 1. List of Ancillary Services parameters.

\begin{tabular}{ccc}
\hline Parameter & Symbol & Description \\
\hline Character (optional/compulsory) & $\mathrm{n} / \mathrm{a}$ & $\begin{array}{c}\text { In optional services, Balance Service Providers (BSP) } \\
\text { decide to provide or not the service. In such cases, BSPs } \\
\text { normally will not receive any compensation if they chose } \\
\text { not to activate their resources. Compulsory services force } \\
\text { BSPs to provide reserve when asked, either by contract or } \\
\text { as a binding auction result, resulting in fines for the } \\
\text { non-provision of it. }\end{array}$ \\
\hline
\end{tabular}

Manual activation is done after the Transmission System Operator (TSO) sends a request so that operators apply

Type of activation (manual/automatic)

$\mathrm{n} / \mathrm{a}$ the correspondent protocol to provide the reserve needed.

This type of activation is frequent among services with

long $\mathrm{T}_{\text {RES }}$ (several minutes or more), such as RR and Supplemental Reserve. Automatic activation is in place for faster responses (a few seconds to a few minutes).

Agents present bids up to a certain time before the action occurs (daily, weekly, monthly, yearly, or only when the TSO requires additional reserve). Yearly, monthly, and weekly auctions tend to have associated capacity payments. Sometimes, BSPs can modify bids up to real time.

\begin{tabular}{|c|c|c|}
\hline Notification time & $\mathrm{T}_{\mathrm{NOT}}$ & Moment when the TSO asks to provide the action \\
\hline Maximum Response Time & $\mathrm{T}_{\text {RES }}$ & $\begin{array}{l}\text { The maximum admissible time between the TSO's } \\
\text { notification and the BSP's full activation. BSP achieves full } \\
\text { activation when it provides all the requested reserve. }\end{array}$ \\
\hline Ramp time & $\mathrm{T}_{\mathrm{RAM}}$ & $\begin{array}{l}\text { Time taken by the BSP to modify its power (either } \\
\text { demand or production), from the beginning of the } \\
\text { modification until the achievement of the targeted power. } \\
\text { Many AS programs do not have any specific } \mathrm{T}_{\text {RAM }} \text { but are } \\
\text { only dependent on } \mathrm{T}_{\text {RES }} \text {. }\end{array}$ \\
\hline Maximum duration & $\mathrm{T}_{\text {MAX }}$ & $\begin{array}{l}\text { The maximum time that the TSO can ask to sustain } \\
\text { the action. }\end{array}$ \\
\hline Minimum capacity & $\Delta \mathrm{P}_{\min }$ & $\begin{array}{c}\text { Minimum reserve that a BSP has to be able to provide to } \\
\text { participate in an AS program. It tends to have the same } \\
\text { value as the minimum size of a bid to be accepted in a } \\
\text { market, but not always. }\end{array}$ \\
\hline $\begin{array}{l}\text { Type of payment } \\
\text { (capacity/energy/security } \\
\text { of supply). }\end{array}$ & $\mathrm{n} / \mathrm{a}$ & $\begin{array}{l}\text { There are three ways to remunerate these services. A } \\
\text { capacity payment that rewards based on the amount of } \\
\text { power that a BSP has available during a certain period. } \\
\text { This price has monetary units per MW and time period. } \\
\text { This reserve can be total or partially activated in case the } \\
\text { TSO requests it, but the BSP obtains the payments } \\
\text { regardless of its activity during the imbalance. An energy } \\
\text { payment values the amount of energy provided by the } \\
\text { BSP during service activation. This price has monetary } \\
\text { units per MWh. Security of supply payment guarantees } \\
\text { the energy supply without interruptions to the agents. }\end{array}$ \\
\hline
\end{tabular}


Table 2. List of Demand Response (DR) parameters.

\begin{tabular}{ccc}
\hline Parameter & Symbol & Description \\
\hline Flexible power & $\Delta \mathrm{P}_{\mathrm{R}}$ & $\begin{array}{c}\text { This is the amount of power that the Demand Response Providers } \\
(\mathrm{DRPV}) \text { can increase and/or decrease during a response action by } \\
\text { managing loads or turning off/on their energy sources. } \mathrm{E}_{1} \\
\text { represents this parameter in the figure and serves to calculate the } \\
\text { energy payment. }\end{array}$
\end{tabular}

\begin{tabular}{|c|c|c|}
\hline Maximum length of the action & $\mathrm{T}_{\mathrm{MAX}, \mathrm{RD}}$ & $\begin{array}{l}\text { This parameter represents for how long the DRPV can keep the } \\
\text { response action working, the maximum time during which the } \\
\text { DRPV can modify its demand from the baseline. }\end{array}$ \\
\hline Time of reaction & $\mathrm{T}_{\mathrm{RCT}}$ & $\begin{array}{l}\text { It represents the minimum time that the DRPV needs to achieve } \\
\text { full activation of the response action }\end{array}$ \\
\hline $\begin{array}{l}\text { Extra power before the } \\
\text { flexibility action }\end{array}$ & $\Delta \mathrm{P}_{\mathrm{R} 2}$ & $\begin{array}{l}\text { Additional maximum power that the DRPV may request before } \\
\text { the response action to prepare its facility. Not all DRPVs need } \\
\text { extra power before the action takes place. } E_{2} \text { represents this extra } \\
\text { energy consumed during the preparation. }\end{array}$ \\
\hline
\end{tabular}

\begin{tabular}{|c|c|c|}
\hline $\begin{array}{l}\text { Extra power after the } \\
\text { flexibility action }\end{array}$ & $\Delta \mathrm{P}_{\mathrm{R} 3}$ & $\begin{array}{l}\text { Additional maximum power that the DRPV may request once the } \\
\text { response action is overdue to technical reasons. Not all DRPVS } \\
\text { need extra power after the action takes place. } E_{3} \text { represents this } \\
\text { extra energy consumed during the recovery. }\end{array}$ \\
\hline Duration of the preparation & $\mathrm{T}_{\mathrm{PRE}}$ & The portion of $\mathrm{T}_{\mathrm{RCT}}$, during which the DRPV demands $\Delta \mathrm{P}_{\mathrm{R} 2}$. \\
\hline Duration of the recovery & $\mathrm{T}_{\mathrm{REC}}$ & $\begin{array}{l}\text { Time after the response action during which the DRPV } \\
\text { demands } \Delta \mathrm{P}_{\mathrm{R} 3 .}\end{array}$ \\
\hline Flexible energy & $\mathrm{E}_{1}$ & $\begin{array}{c}\text { This is the amount of energy that the DRPV can consume or stop } \\
\text { consuming during a response action by managing loads or } \\
\text { turning off/on their energy sources. It serves to calculate the } \\
\text { energy payment. }\end{array}$ \\
\hline $\begin{array}{l}\text { Extra energy before the } \\
\text { flexibility action }\end{array}$ & $\mathrm{E}_{2}$ & $\begin{array}{l}\text { Additional energy that the DRPV may request before the } \\
\text { response action to prepare its facility. Not all DRPVs need extra } \\
\text { energy before the action takes place. }\end{array}$ \\
\hline $\begin{array}{l}\text { Extra energy after the } \\
\text { flexibility action }\end{array}$ & $E_{3}$ & $\begin{array}{l}\text { Additional maximum energy that the DRPV may request once the } \\
\text { response action is overdue to technical reasons. Not all DRPVs } \\
\text { need extra energy after the action takes place. }\end{array}$ \\
\hline Ramp time & $\mathrm{T}_{\mathrm{RAM}, \mathrm{RD}}$ & $\begin{array}{l}\text { The portion of } \mathrm{T}_{\mathrm{RCT}} \text { used by the DRPV to adapt its consumption } \\
\text { from the baseline to the targeted power. It is the time taken from } \\
\text { the start of demand modification until the achievement of the } \\
\text { targeted power. }\end{array}$ \\
\hline Operation times & $\mathrm{n} / \mathrm{a}$ & $\begin{array}{l}\text { Times slots when the DRPV declares that its services can be } \\
\text { activated. This can include schedules depending on the day } \\
\text { (weekday or weekend) or available days within a season, } \\
\text { according to the technical flexibility of the DRPV. Also known as } \\
\text { the "availability window". }\end{array}$ \\
\hline $\begin{array}{l}\text { Minimum time between } \\
\text { interruptions }\end{array}$ & $\mathrm{n} / \mathrm{a}$ & $\begin{array}{l}\text { The time that the DRPV needs to take between two consecutive } \\
\text { actions. The time between the end of one action and the } \\
\text { beginning of the next one. }\end{array}$ \\
\hline Baseline & $\mathrm{n} / \mathrm{a}$ & $\begin{array}{l}\text { Load curve that the DRPV would have theoretically had if it had } \\
\text { not performed a response. It is crucial for the calculation of the } \\
\text { energy payment received by the DRPV. This parameter must be } \\
\text { exhaustive and clear, and the contract between the two parties } \\
\text { must reflect it. ENERNOC presents different methodologies to } \\
\text { calculate the baseline [30]. }\end{array}$ \\
\hline Type of activation & $\mathrm{n} / \mathrm{a}$ & $\begin{array}{l}\text { Agents activate DR either automatically or manually, depending } \\
\text { on DRPV's flexibility and technical resources. Actions can have a } \\
\text { manual activation and still be mandatory for the DRPV. }\end{array}$ \\
\hline
\end{tabular}




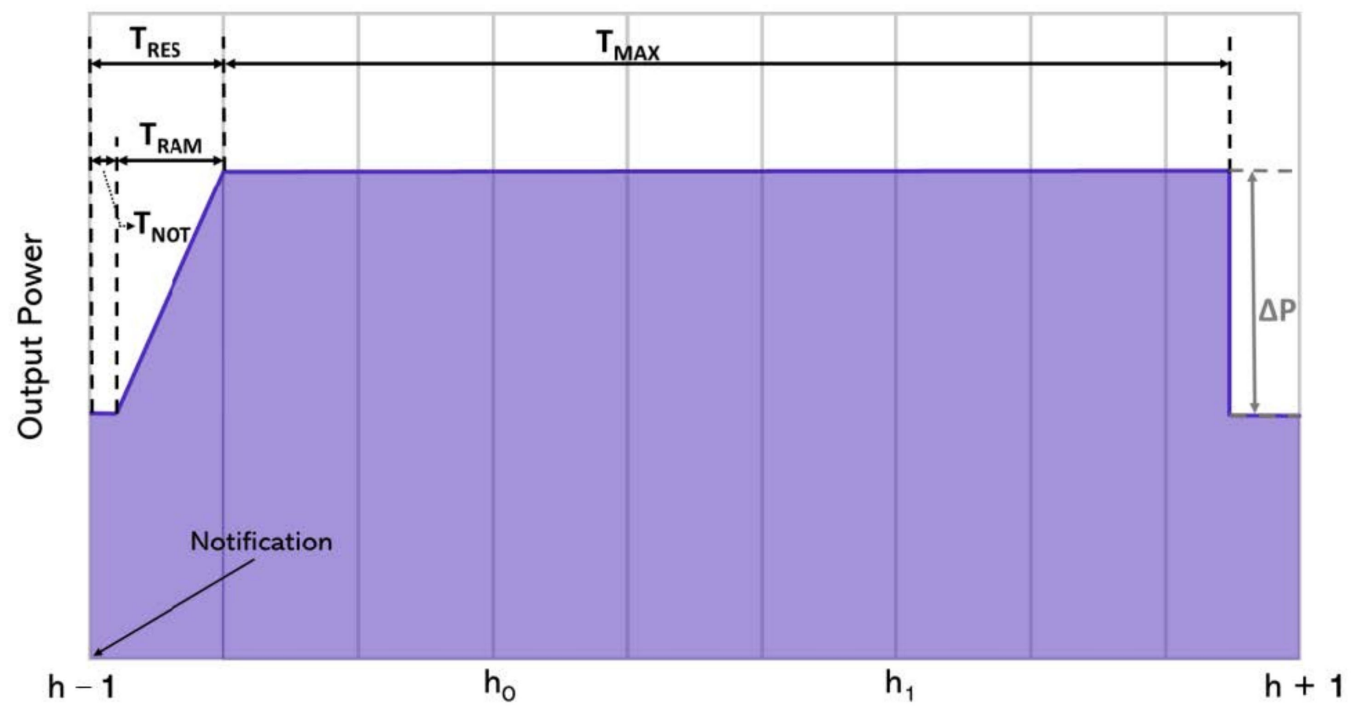

Figure 2. Representation of an ancillary service's requirements. $\mathrm{T}_{\mathrm{RES}}$ : maximum response time; $\mathrm{T}_{\mathrm{MAX}}$ : maximum duration; $\mathrm{T}_{\mathrm{RAM}}$ : ramp time.

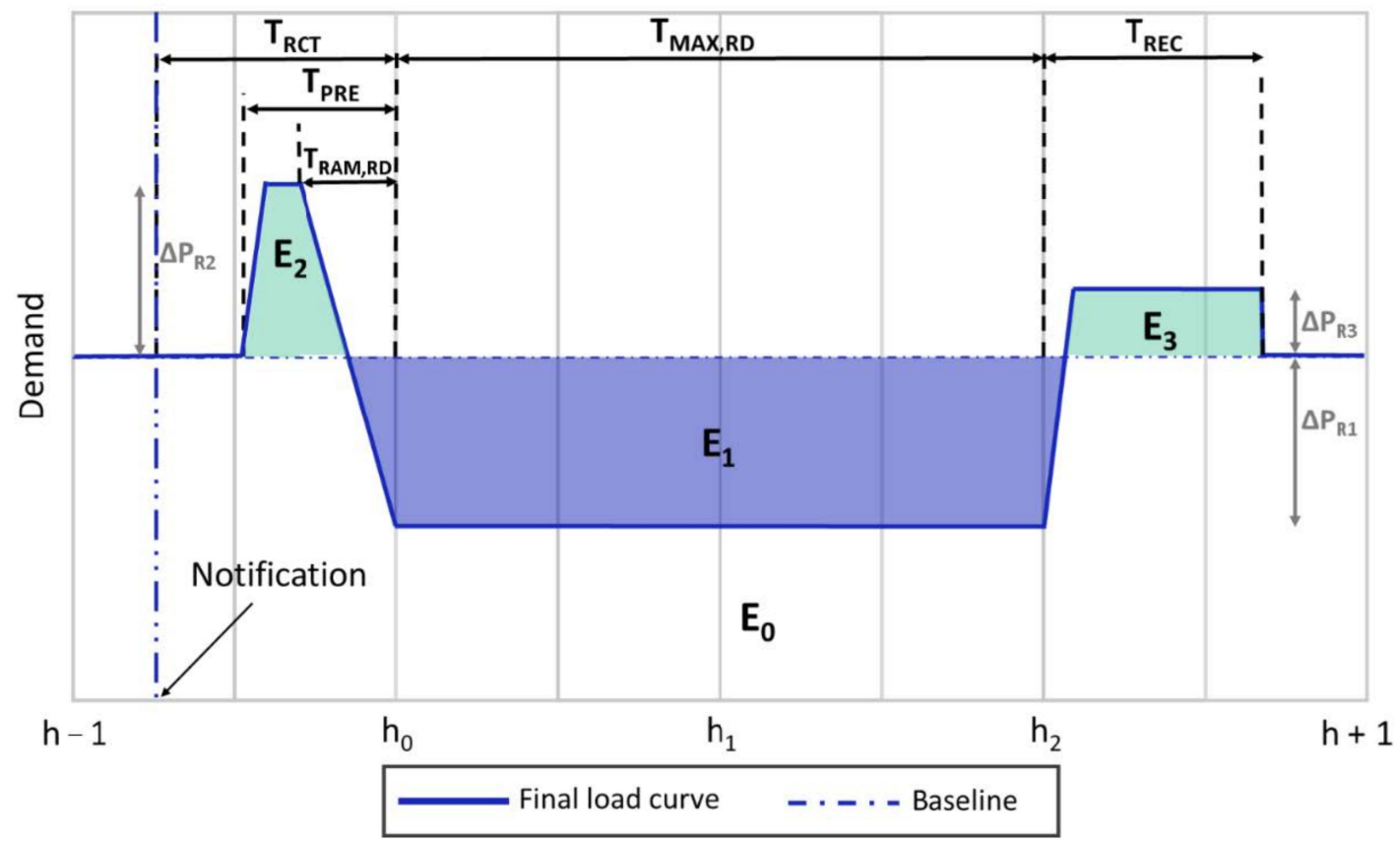

Figure 3. Representation of a DR action and its main parameters.

\subsection{Assessment Methodology}

Figure 4 shows the developed methodology to study and compare the different DRP. The first action of the developed methodology consists of the gathering and filtration of general information to construct a list of DRPs. For this first gathering of information, general reports serve as a start. DR works not only as a balancing tool but also in the spot markets [15]; these programs are out of the scope of this analysis. Here, the methodology discards all the products that do not provide AS.

The information needs a common structure, but products coming from several TSOs have different parameter names when in fact, they represent the same concept due to the lack of standardization [31]. To homogenize this series of products, the methodology uses the same terms for the same concept, regardless of their original names. A list of 
DR parameters like the one presented in Section 2.3 has this purpose. The output of this process is a list of parametrized products.

Once all products are characterized, it is possible to classify them according to the criterion of interest. For instance, depending on the TRCT, the method sets several intervals of time and places each product on its corresponding rank. In our case, the classification follows the ones used by FERC and ENTSO-E. First, we check what kind of services both nomenclatures consider and how they define each of them. After this, we compare our list of parametrized products with these definitions so that it was effortless, for instance, to classify the European products under the American nomenclature and vice versa.

After the classification, the method continues with a review of the success or failure of every product and relate it to their traits and circumstances. The output of this analysis is a series of conclusions regarding what aspects influence the effective participation of DR in the AS and to what extent.

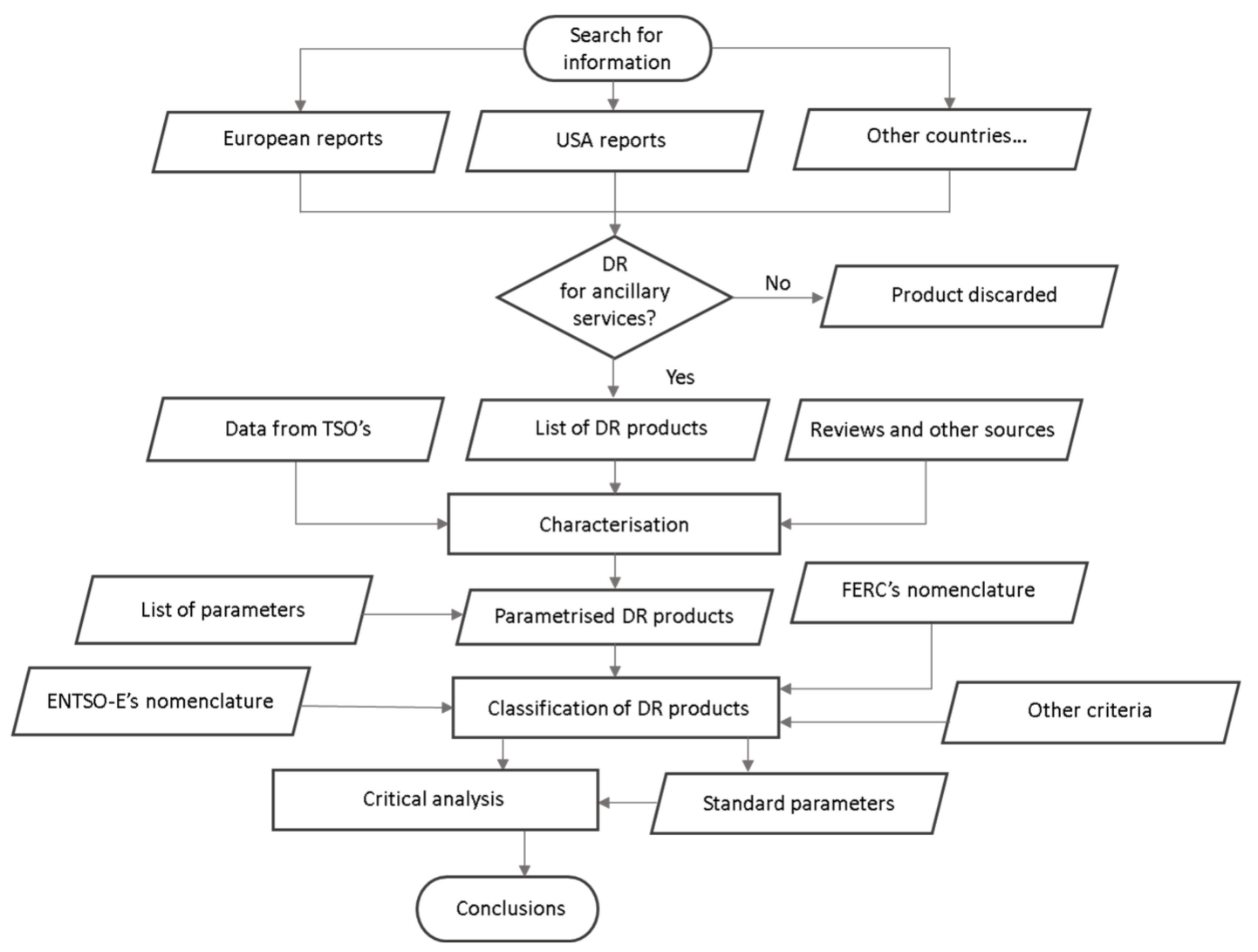

Figure 4. Proposed methodology.

\subsection{Consulted Documents}

Regarding the search for DR products, there are several reliable sources to start with; depending on the country of interest, the information is normally provided by the TSO or market operator. For a more general view, in the case of the European countries, there is an extensive report prepared by the Smart Energy Demand Coalition [32] with information about DR programs from 18 different European countries. However, this report came out in 2017, and since DR is rapidly growing in Europe [15], some of its information is already out of date.

The Regulatory Assistance Project prepared in 2013 a report which presents the history and trends of DR in the United States [33]. Another source that is interesting and more updated is the Independent System Operator and the Regional Transmission Organization Council's document referenced in [34]. 
The Asia-Pacific region was reviewed by [35]. In some cases, especially when a country's electricity system has been recently open to DR, there may not be enough information to correctly characterize its products. Normally, in these countries, data is very short and/or has no English translation. Another problem that can be even harder to tackle is restricted or private information. Some TSOs prepare reports with technical and economic data on DR regularly, but they are only available for market participants. In this case, unless the TSO allows the researchers to access such reports, it will be harder to identify the state of DR in these countries. In this case, the best possible action seems to be to use a secondary source, such as general reports or reviews prepared from these primary sources.

Finally, DR information becomes rapidly out of date due to the quick evolution of electricity markets. In some cases, either because of imperfect market design, unexpected reactions of the stakeholders, or incapacity to encourage demand participation. Consequently, TSOs may want to modify their rules or even withdraw them from the market. Additionally, prices and the share of demand side on AS may widely vary from one year to another. To avoid using outdated information, we searched for the most recent reports and reviews. Furthermore, when it was possible, we contrasted data from international reviews with numbers in reports prepared by each TSO. In some cases, we found recent data on prices and energy volumes, but also old data on market rules and procedures that are three to six years old. In front of these situations, we assume that rules have stayed unchanging during the last years, adding some uncertainty to the analysis.

\section{Demand Response around the World: Main Application}

\subsection{Europe}

Many European countries opened most of their AS to DR with the same rules as generation resources to compete to provide capacity. Many TSOs adjusted the technical requirements of these services to match what DRPVs can do. In many other cases, TSOs only developed special programs for Demand Side Resources (DSR) to assure DR participation in front of strong competitors or too demanding technical requirements. At the end of this section, Tables 3-6 contain the main parameters that characterize the different programs open to DR in European AS markets.

\subsubsection{Belgium}

In Belgium, both FCR and mFRR are open to DR. Moreover, there is an Interruptible Service especially designed for load curtailment and a Strategic Reserve, in which DSR represented $10 \%$ of total reserves in 2017 [28]. However, AS exclude residential consumers even if they could provide more than $4700 \mathrm{MW}$ of reserve [32]. The Belgian mFRR has two different resources. On the one hand, monthly bids on the market of Reserved Volumes, where the service only has an availability payment, and technical requirements vary between Standard R3 and Flex R3 product. The DRPV can choose which kind of product to offer according to their flexibility. Successful bidders in these auctions acquire the responsibility to respond under TSO's request subject to fines. On the other hand, DRPVs can present bids continuously on the market of Non-Reserved Volumes, up to 15 min before the service activation, to obtain an energy payment [33]. Regarding the Interruptible Service, as in the case of Reserved Volumes, there are three products with different requirements. In all cases, the maximum response time $\left(\mathrm{T}_{\mathrm{RES}}\right)$ has the same value, but the maximum duration $\left(\mathrm{T}_{\mathrm{MAX}}\right)$ is very different from one product to another [28]. This principle makes it easier to match what DSRs can do with what TSO needs.

\subsubsection{Denmark}

DR activity in Denmark remains low, even if all electricity markets are open to it. A generator-based design and the scarce need for reserve in this country may be the main reasons for this slow development. Nevertheless, the constant growth of renewable energies will likely increase the necessity of DR to assure the system's reliability. Denmark 
divides its power system into two zones. DK1, on the West, is part of the joint continental FCR market, while DK2, on the East, is part of the Nordic synchronous area. Therefore, FCR functions differently according to the corresponding zone [34]. On the contrary, mFRR rules are the same, regardless of the zone of application. In this service, bids can be upwards or downwards, but a combination of both is not acceptable. The service is remunerated with an energy payment whose minimum (or maximum, for the downwards reserve) price is the electricity price in the spot market.

\subsubsection{Finland}

All AS accept DR in Finland, although its participation varies among the different services. For instance, the DR share in aFRR was absent in 2018, while in mFRR it reached $400 \mathrm{MW}$. Close to the aFRR's case, DR reserves on FCR added only 4 MW [36]. Some of the most relevant barriers identified are lack of economic benefit, absence of a communication standard, and low motivation for consumers to be involved in load management [37]. Still, around $1800 \mathrm{MW}$ of loads can be remotely controlled. This represents more than $10 \%$ of peak demand in Finland, which in 2014 reached 14,200 MW. FCR is procured through an annual and hourly market, in both cases paid with an availability payment only. In the annual auction, BSPs receive the price for their reserves, which will vary from one day to the next one, and the Finnish TSO acquires all usable capacity at the price determined in the auction. On the other hand, other BSPs can present bids with their reserves daily, and the TSO purchases only the amount needed [38]. There is a Strategic Reserve used to compensate for higher demand in winter. Technical requirements are like mFRR, and the remuneration is agreed upon in a private contract. In 2018, DR reached 22 MW of capacity in this service [36].

\subsubsection{France}

France was one of the first European countries to open its electricity markets to DR. In 2003, industrial consumers were already able to offer their flexibility on the balancing mechanism. In 2011, mFRR opened to DR, and in 2018, it accounted for more than 50\% of the Rapid Reserve. Since 2014, industrial consumers larger than $1 \mathrm{MW}$ have got the chance to participate in FCR [39]. The energy used in the French balancing mechanism, all provided by DR reached 22 GWh in 2018, and the maximum DR reserve activated simultaneously exceeded 1000 MW [39]. There is also a mechanism in France called "Demand Response Call for Tenders", designed to promote DR development. It is closed for conventional means of self-generation, and consumers already benefited from the Interruptible Load service. The total capacity provided by this mechanism reached $2900 \mathrm{MW}$ in 2020. In aFRR, BSPs have three products, each of which has its own $\mathrm{T}_{\mathrm{RES}}$ requirement. Bids in this service require symmetry and activate at the pro rata of the BSP's obligation. On the other hand, mFRR and RR have very similar traits, with the biggest difference in $T_{\text {RES }}$ and the price of the payments, being RR cheaper as it is a less demanding service (higher $\mathrm{T}_{\mathrm{RES}}$ ).

\subsubsection{Germany}

Germany has a strong industrial sector that has a potential of $6.4 \mathrm{GW}$ DR capacity available for $1 \mathrm{~h}$ at least [40], with DR investments around 10 times smaller than capacity provided by traditional generation, while operation and maintenance costs are dependent on each manufacturing process [41]. Estimations show that the tertiary sector could provide up to $3.8 \mathrm{GW}$ [42]. FCR, aFRR, and mFRR services are all open to DR, and there is an Interruptible Service especially designed for DSRs. aFRR bids are weekly presented in a joint market with Austria. The service requires full availability for $12 \mathrm{~h}$ a day and a minimum size of the bid of $5 \mathrm{MW}$ (1 MW if only one bid is presented) [43], but these requisites will be modified soon to fit more DR to AS [32]. mFRR auctions occur only during weekdays, and availability is required for $4 \mathrm{~h}$ instead of 12 . It is possible that coming changes would make new aFRR's design more like current mFRR's. 


\subsubsection{Ireland}

The rapid growth of wind energy in Ireland has created an increasing need for flexibility, so the Irish TSO works on specific programs to take advantage of DSRs. In 2017, 19 DRPVs were registered to provide a reserve, with a total capacity of 362 MW [44]. Demand Side Units (DSUs) are DRPVs participating in the capacity market, with a reserve no smaller than $4 \mathrm{MW}$ that can be aggregated from smaller units, not subject to further size limitations. These units are asked to manually modify their load curve with a $T_{\text {RES }}$ of $1 \mathrm{~h}$, and they will be rewarded with an annual capacity payment since they must be available any day, at any time. Powersave is a service designed to reduce load when total demand is close to the available generation capacity. DRPVs with a reserve no smaller than $0.1 \mathrm{MW}$ can participate during working days in exchange for an energy payment [32].

\subsubsection{The Netherlands}

Most of the AS in the Netherlands are open to DR. In 2017, the Dutch TSO purchased $1.5 \mathrm{GW}$ of capacity provided by DSRs, with a total activation of $500 \mathrm{GWh}$. Distribution System Operators and retailers are starting to see demand management as an attractive business [32]. One particularity of aFRR in the Netherlands is its activation logic. When the TSO detects an ordinary frequency deviation, it activates the reserves by merit order, so that only those BSPs who presented the cheapest bids are activated. However, if the TSO detects an "extraordinary" deviation, it will activate all resources at the pro rata of the BSP's obligation to achieve the biggest possible power ramp [45]. This solves the contingency faster, and BSPs get a higher energy payment. There is also a capacity payment determined in an annual auction. The Dutch mFRR services treat upward and downward reserves separately. A single unit can only present one type of reserve, while groups of BSPs can participate in both markets at the same time. Consumers with a contracted power of $60 \mathrm{MW}$ or higher must present their reserves in mFRR. $\mathrm{T}_{\text {RES }}$ and the calculation of the price for the energy payment are different for upward and downward reserves. Such prices depend on the spot market price.

\subsubsection{Sweden}

Sweden is divided into four zones, SE1, SE2, SE3, and SE4. Sometimes certain parameters of AS vary within those zones. Sweden is a country with large water resources, and its capacity reserves come from northern hydroelectric plants. Some thermal plants also activate when there is a congestion problem or during peak load periods. Swedish FCR, aFRR, and mFRR are all open to DR and aggregation, but sometimes technical requirements prevent many DRPVs from participating in them. For instance, the minimum capacity $\left(\Delta \mathrm{P}_{\min }\right)$ is $5 \mathrm{MW}$ in SE4 and $10 \mathrm{MW}$ in the rest of the country, making it difficult for most consumers to meet such requirements and enter the mFRR market. The service has an energy payment only [32]. There is a Strategic Reserve to be $25 \%$ provided by DSRs. The technical requirements of the Strategic Reserve are like mFRR's, but the service has a capacity and an energy payment.

\subsubsection{Switzerland}

In 2013, Switzerland became one of the most advanced countries in DR development in Europe. The legislation clearly defines BSP's roles and mitigates costs and risks. The closure of nuclear power plants and water scarcity may increase the need for flexibility in Switzerland in the coming years [46]. All AS are open to DR and aggregation, and in 2017 [47], DR provided $3 \mathrm{MW}$ of reserve in FCR, $10 \mathrm{MW}$ in aFRR, and $49 \mathrm{MW}$ in mFRR [32]. aFRR in Switzerland has some particularities. Bids take place in a weekly auction and must be symmetric, while the activation occurs at the pro rata of the $\mathrm{BSP}^{\prime} \mathrm{s}$ obligation. $\Delta \mathrm{P}_{\min }$ is $5 \mathrm{MW}$, and the remuneration is based on a capacity payment dependent on the weekly auction and an energy payment dependent on the spot market price [48]. Bids for mFRR take place weekly and daily. The weekly auction accepts bids for any hour during the week, while the daily auction has six blocks of $4 \mathrm{~h}$. Products do not have to be symmetric 
in this service, but they must be larger than $5 \mathrm{MW}$ too. $\mathrm{T}_{\mathrm{RES}}$ depends on the direction of the reserve (upwards or downwards) and the type of auction [48].

\subsubsection{United Kingdom}

Most of the British ASs are open to DR and aggregation, although its participation remains low in some of them. The British TSO adjusted several market rules and requirements to increase this participation that had as main barriers to the complexity and excess of regulatory changes [32]. Demand Turn Up is a service designed to decrease generation or increase consumption in times of low demand and high renewable generation. The activation of this service can only be done within a certain schedule, and $\mathrm{T}_{\text {RES }}$ and $\mathrm{T}_{\mathrm{MAX}}$ do not have fixed values but are based on what each BSP can offer. In 2018, 115 MW of reserve provided this service, with total usage of $1465 \mathrm{MWh}$. Short-Term Operating Reserve (STOR) used to be the most important program in the UK, but decreasing prices have discouraged many DRPVs from participating in it. This service is like ENTSO-E's standard Supplemental Reserve. There are three different products within the STOR program, with technical traits and a reward based on capacity and an energy payment. Annual auctions of BSPs determine prices for the next seasons [49]. The Fast Reserve demands a $\Delta \mathrm{P}_{\min }$ of $25 \mathrm{MW}$, where only very large consumers can access it and compete with generators and storage units. Rapid Reserve's technical requirements make it like aFRR, and the service rewards three concepts: capacity, energy, and nomination. Nomination payment depends on the time provided and not on actual activation nor capacity provided [50,51].

Table 3. FCR programs in Europe open to DR: Main parameters.

\begin{tabular}{|c|c|c|c|c|c|}
\hline $\begin{array}{l}\text { Product/Service } \\
\text { (Country) }\end{array}$ & $\begin{array}{c}\text { Type of } \\
\text { Activation }\end{array}$ & $\mathbf{T}_{\text {RES }}$ & $\Delta \mathbf{P}_{\min }$ & $\mathbf{T}_{\text {MAX }}$ & $\begin{array}{l}\text { Type(s) of } \\
\text { Payment }\end{array}$ \\
\hline RR (France) & Manual & $30 \mathrm{~min}$ & $10 \mathrm{MW}$ & $90 \mathrm{~min}$ & $\begin{array}{c}\text { Capacity and } \\
\text { energy }\end{array}$ \\
\hline $\begin{array}{c}\text { Demand Turn Up } \\
\text { (United Kingdom) }\end{array}$ & Manual & $\begin{array}{c}\text { Variable, Average: } \\
6 \mathrm{~h}\end{array}$ & $1 \mathrm{MW}$ & $\begin{array}{c}\text { Variable, Average: } \\
4.5 \mathrm{~h}\end{array}$ & Energy only \\
\hline $\begin{array}{c}\text { Short-Term } \\
\text { Operating Reserve } \\
\text { (STOR) } \\
\text { (United Kingdom) }\end{array}$ & Manual & Variable, $20 \mathrm{~min}-4 \mathrm{~h}$ & $3 \mathrm{MW}$ & $\mathrm{n} / \mathrm{a}(\min : 2 \mathrm{~h})$ & $\begin{array}{c}\text { Capacity and } \\
\text { energy }\end{array}$ \\
\hline $\begin{array}{c}\text { Interruptible } \\
\text { Service (Belgium) }\end{array}$ & Manual & $15 \mathrm{~min}$ & $5 \mathrm{MW}$ & $4-12 \mathrm{~h}$ & Capacity only \\
\hline $\begin{array}{l}\text { Strategic demand } \\
\text { reserve (Belgium) }\end{array}$ & Manual & $90 \mathrm{~min}$ & $1 \mathrm{MW}$ & $4 \mathrm{~h}$ & $\begin{array}{c}\text { Capacity and } \\
\text { energy }\end{array}$ \\
\hline FCR (Finland) & Automatic & $3 \mathrm{~min}$ & $0.1 \mathrm{MW}$ & $\mathrm{n} / \mathrm{a}$ & $\begin{array}{c}\text { Capacity and } \\
\text { energy }\end{array}$ \\
\hline FCR (Sweden) & Automatic & $3 \mathrm{~min}$ & $0.1 \mathrm{MW}$ & $\mathrm{n} / \mathrm{a}$ & $\begin{array}{c}\text { Capacity and } \\
\text { energy }\end{array}$ \\
\hline
\end{tabular}


Table 4. aFRR programs in Europe open to DR: Main parameters.

\begin{tabular}{|c|c|c|c|c|c|}
\hline $\begin{array}{l}\text { Product/Service } \\
\text { (Country) }\end{array}$ & $\begin{array}{c}\text { Type of } \\
\text { Activation }\end{array}$ & $\mathrm{T}_{\mathrm{RES}}$ & $\Delta \mathbf{P}_{\min }$ & $\mathrm{T}_{\text {MAX }}$ & Type(s) of Payment \\
\hline aFRR (France) & Automatic & $60-100 \mathrm{~s}$ & $1 \mathrm{MW}$ & $\mathrm{n} / \mathrm{a}$ & Capacity and energy \\
\hline aFRR (Germany) & Automatic & $5 \mathrm{~min}$ & $5 \mathrm{MW}$ & $\mathrm{n} / \mathrm{a}$ & Capacity and energy \\
\hline $\begin{array}{l}\text { aFRR (The } \\
\text { Netherlands) }\end{array}$ & Automatic & $>30 \mathrm{~s}$ & $1 \mathrm{MW}$ & $15 \mathrm{~min}$ & Capacity and energy \\
\hline aFRR (Sweden) & Automatic & $120 \mathrm{~s}$ & $5 \mathrm{MW}$ & $\mathrm{n} / \mathrm{a}(\min 1 \mathrm{~h})$ & Capacity and energy \\
\hline $\begin{array}{c}\text { aFRR } \\
\text { (Switzerland) }\end{array}$ & Automatic & $200 \mathrm{~s}$ & $5 \mathrm{MW}$ & $\mathrm{n} / \mathrm{a}$ & Capacity and energy \\
\hline $\begin{array}{l}\text { Rapid Reserve } \\
\text { (United Kingdom) }\end{array}$ & Automatic & $2 \mathrm{~min}$ & $25 \mathrm{MW}$ & $15 \min$ & $\begin{array}{c}\text { Nomination, capacity, } \\
\text { and energy }\end{array}$ \\
\hline
\end{tabular}

Table 5. mFRR programs in Europe open to DR: Main parameters.

\begin{tabular}{|c|c|c|c|c|c|}
\hline $\begin{array}{l}\text { Product/Service } \\
\text { (Country) }\end{array}$ & $\begin{array}{c}\text { Type of } \\
\text { Activation }\end{array}$ & $\mathbf{T}_{\text {RES }}$ & $\Delta \mathbf{P}_{\min }$ & $\mathbf{T}_{\text {MAX }}$ & Type(s) of Payment \\
\hline $\begin{array}{c}\text { mFRR-Reserved } \\
\text { Volumes (Belgium) }\end{array}$ & Manual & $15 \mathrm{~min}$ & $1 \mathrm{MW}$ & $2-8 \mathrm{~h}$ & Capacity only \\
\hline $\begin{array}{l}\text { mFRR-Non- } \\
\text { Reserved Volumes } \\
\text { (Belgium) }\end{array}$ & Manual & $15 \mathrm{~min}$ & $1 \mathrm{MW}$ & $2-8 \mathrm{~h}$ & Energy only \\
\hline mFRR (Denmark) & Manual & $15 \mathrm{~min}$ & $5 \mathrm{MW}$ & $\mathrm{n} / \mathrm{a}$ & Energy only \\
\hline mFRR (Finland) & Manual & $15 \mathrm{~min}$ & $5 \mathrm{MW}$ & $\mathrm{n} / \mathrm{a}$ & Capacity and energy \\
\hline $\begin{array}{l}\text { Strategic Reserve } \\
\quad \text { (Finland) }\end{array}$ & Manual & $15 \mathrm{~min}$ & $10 \mathrm{MW}$ & $\mathrm{n} / \mathrm{a}$ & According to contract \\
\hline mFRR (France) & Manual & $13 \mathrm{~min}$ & $10 \mathrm{MW}$ & $2 \mathrm{~h}$ & Capacity and energy \\
\hline mFRR (Germany) & Manual & $15 \mathrm{~min}$ & $1 \mathrm{MW}$ & $4 \mathrm{~h}$ & Capacity and energy \\
\hline $\begin{array}{c}\text { mFRR } \\
\text { (The Netherlands) }\end{array}$ & Manual & $10-15 \mathrm{~min}$ & $20 \mathrm{MW}$ & $1 \mathrm{~h}$ & Energy only \\
\hline mFRR (Sweden) & Manual & $15 \mathrm{~min}$ & $10 \mathrm{MW}$ & $\mathrm{n} / \mathrm{a}$ & Energy only \\
\hline $\begin{array}{l}\text { Strategic Reserve } \\
\text { (Sweden) }\end{array}$ & Manual & $15 \mathrm{~min}$ & $5 \mathrm{MW}$ & $\mathrm{n} / \mathrm{a}$ & Capacity and energy \\
\hline $\begin{array}{c}\text { mFRR } \\
\text { (Switzerland) }\end{array}$ & Manual & $15-35 \mathrm{~min}$ & $5 \mathrm{MW}$ & $\mathrm{n} / \mathrm{a}$ & Capacity and energy \\
\hline
\end{tabular}

Table 6. RR programs in Europe open to DR: Main parameters.

\begin{tabular}{|c|c|c|c|c|c|}
\hline $\begin{array}{l}\text { Product/Service } \\
\text { (Country) }\end{array}$ & $\begin{array}{c}\text { Type of } \\
\text { Activation }\end{array}$ & $\mathbf{T}_{\text {RES }}$ & $\Delta \mathbf{P}_{\min }$ & $\mathbf{T}_{\text {MAX }}$ & $\begin{array}{l}\text { Type(s) of } \\
\text { Payment }\end{array}$ \\
\hline $\begin{array}{c}\text { Interruptible } \\
\text { Service (Belgium) }\end{array}$ & Manual & $15 \mathrm{~min}$ & $5 \mathrm{MW}$ & $4-12 \mathrm{~h}$ & Capacity only \\
\hline $\begin{array}{l}\text { Strategic demand } \\
\text { reserve (Belgium) }\end{array}$ & Manual & $90 \mathrm{~min}$ & $1 \mathrm{MW}$ & $4 \mathrm{~h}$ & $\begin{array}{c}\text { Capacity and } \\
\text { energy }\end{array}$ \\
\hline RR (France) & Manual & $30 \mathrm{~min}$ & $10 \mathrm{MW}$ & $90 \mathrm{~min}$ & $\begin{array}{c}\text { Capacity and } \\
\text { energy }\end{array}$ \\
\hline $\begin{array}{l}\text { Demand Turn Up } \\
\text { (United Kingdom) }\end{array}$ & Manual & Variable, Average: $6 \mathrm{~h}$ & $1 \mathrm{MW}$ & $\begin{array}{c}\text { Variable, Average: } \\
4.5 \mathrm{~h}\end{array}$ & Energy only \\
\hline $\begin{array}{l}\text { STOR (United } \\
\text { Kingdom) }\end{array}$ & Manual & Variable, $20 \mathrm{~min}-4 \mathrm{~h}$ & $3 \mathrm{MW}$ & $\mathrm{n} / \mathrm{a}(\min : 2 \mathrm{~h})$ & $\begin{array}{c}\text { Capacity and } \\
\text { energy }\end{array}$ \\
\hline
\end{tabular}




\subsection{North America}

Many North American systems allow DR to access AS markets with similar rules than generation resources to compete to provide capacity. Several TSOs adjusted the technical requirements of these services to match what DRPVs can do. In many other cases, TSOs developed only special programs for DSRs to assure DR participation in front of strong competitors or too demanding technical requirements. At the end of this Section, Tables 7 and 8 contain the main parameters that characterize North American AS for DR.

\subsubsection{California Independent System Operator (CAISO)}

California Independent System Operators (CAISOs) DRPs participate directly in the region capacity market jointly with the other products [52,53], and California DSOs have maintained traditional load disruption and load shifting programs [54]. California has $1612 \mathrm{MW}$ of DR resources in economic programs that reduce the load based on anticipated offset prices in real-time markets [55]. The most relevant DRP in the region is a Load Following Service, which is part of the CAISO regulator. As in most of the country's products, aggregation is allowed. The remuneration is based on a capacity payment where CAISO, in accordance with clients, must agree when they have to offer the service. In turn, and depending on the agreement signed, they are notified in advance in the Day-Ahead Market (13:00), and in Real Time (based on the offer options): $2.5 \mathrm{~min}, 22.5 \mathrm{~min}, 52.5 \mathrm{~min}$. The $\mathrm{T}_{\mathrm{REC}}$ depends on the parameters of the resources used. Other relevant products of the electricity system have also been developed from different TSOs and DSOs in California. The Pacific Gas and Electric Company (PGE), Southern California Edison Company (SCE), and San Diego Gas and Electric Company (SDGE) have also specific programs used during critical periods of demand, contributing to load shifting.

\subsubsection{Electric Reliability Council of Texas (ERCOT)}

The Electric Reliability Council of Texas (ERCOT) has several DRP that participate in AS like Non-Spinning Reserve Services, Supplemental Reserve Services (Climate-sensitive, Non-climate-sensitive, and Load Resource), and Regulation Services [56,57]. Due to its climatic conditions and particularities, ERCOT has a different range of DRP regarding if they occur on a normal basis or under specific climatic conditions. The Non-Climatesensitive products can be identified as Non-Spinning Reserve and Supplemental Reserve, which features a $\Delta \mathrm{P}_{\min }$ of $100 \mathrm{~kW}$ and a minimum reduction amount of $100 \mathrm{~kW}$ for both $\mathrm{T}_{\text {RAM }}$ options, $10 \mathrm{~min}$ or $30 \mathrm{~min}$. Remuneration is in the form of security of supply, the $\mathrm{T}_{\mathrm{MAX}}$ will last $12 \mathrm{~h}$, and the period in which customers must offer the service will be established based on the service paid time [58]. The Climate-sensitive products are similar to the previous ones, with the main differences that Climate-sensitive programs are used during the peak loads in summer and winter seasons, have a $\Delta \mathrm{P}_{\min }$ of $500 \mathrm{~kW}$ with a minimum reduction amount of $500 \mathrm{~kW}$ and a shorter $\mathrm{T}_{\mathrm{MAX}}$ of $3 \mathrm{~h}$. The Non-Spinning Reserve Service "Load Resource" has similar characteristics as the Non-Spinning Reserve/Non-Climatesensitive service, with the differences that aggregation is not allowed, the $\mathrm{T}_{\mathrm{MAX}}$ where the period in which customers must offer the service will be an agreed interval is shorter and the $T_{\text {RAM }}$ is $10 \mathrm{~min}$ (Verbal), 30 cycles (Retransmission) [59]. The Regulation Service does not allow aggregation, the remuneration will be in the form of security of supply, and the period in which customers must offer the service will be an agreed interval [59].

\subsubsection{New England Independent System Operator (NE-ISO)}

The New England Independent System Operator (NE-ISO) spent many years designing the first installed capacity market in the country [60]. With the adoption of the direct capacity market, DR could participate directly in the market, and two capacity programs were established: real-time demand response and real-time emergency generation. Realtime demand response refers to a reduction in energy use at an end-use customer's facility, while Real-time Emergency Generation refers to a customer-controlled on-site generator, which has environmental permits that limit its operation to "emergency" hours when the 
system operator calls them to avoid lowering the load. The NE-ISO offers several programs that are active today. Regarding AS managed by the NE-ISO, Regulation Services are the main activity to handle demand flexibility, and they include seasonal and no seasonal products [61]. The Regulation service products have a common $\Delta \mathrm{P}_{\min }$ of $100 \mathrm{~kW}$, a minimum reduction amount of $1 \mathrm{~kW}$. The period in which customers must offer the service could be seasonal and in peak hours, in summer between June and August (14:00 to 17:00) and in winter from December to January (18:00 to 19:00) or in summer between June and August and in winter from December to January, on non-holiday days. The notification of the action is defined by market regulators, which inform the members of the program some months or years in advance on when they must provide the service. Therefore, the contract includes a capacity payment on an annual basis $[62,63]$.

\subsubsection{Midcontinent Independent System Operator (MISO)}

The Midcontinent Independent System Operator (MISO) is a TSO responsible for managing $180 \mathrm{GW}$ of installed power to supply around 670 TWh of electricity to 42 million people each year [64]. MISO distinguishes between two types of DRPV. Type I supplies a fixed reserve by load curtailment only, and it does not have generation resources. Type II supplies a continuous range of reserve through load curtailment or self-generation [65]. Regarding AS managed by MISO, Regulation, Spinning Reserve, and Supplementary Reserve are all open to DR, with a common $\Delta \mathrm{P}_{\min }$ of $1 \mathrm{MW}$. Regulation is only open to DRPV type I and requires a very demanding $\mathrm{T}_{\text {RES }}(4 \mathrm{~s})$. BSPs must respond automatically to deviations in frequency and provide both upwards and downwards reserve [66]. Spinning Reserve and Supplementary Reserve are open to DRPV type I and type II. Any DRPV qualified for Regulation is qualified for Spinning Reserve too, and any DRPV qualified for Spinning Reserve is also qualified for Supplementary Reserve [66]. This is due to the respective technical requirements of each service since Regulation is the most demanding while Supplementary Reserve is the least.

\subsubsection{New York Independent System Operator (NYISO)}

The New York Independent System Operator (NYISO) manages its Installed Capacity Market to guarantee the adequacy of the resources for its territory of a state with a maximum load of just over 33,000 MW [67]. The operator of the New York Independent System (NYISO) offers four DR programs that could be identified as Spinning Reserve Service, Regulation Service, and two Supplemental Reserve Services [68]. The DRPs of Spinning Reserve Service, the first Supplemental Reserve Service, and the Regulation Service have a $\Delta \mathrm{P}_{\text {min }}$ of $1 \mathrm{MW}$, a minimum reduction amount of $1 \mathrm{MW}$. The remuneration is economic (based on the capacity provided) in the three programs, the action lasts the established interval (between NYISO and the agent), and the period in which the clients must offer the service is continuous. Prior notification is made in the Daily Market (11:00) and in real time (75 min, $5 \mathrm{~min}$ if Regulation Service). The second Supplemental Reserve Service has a $\Delta \mathrm{P}_{\min }$ of $100 \mathrm{~kW}$ (per zone), a minimum reduction amount of $100 \mathrm{~kW}$ (per zone). Remuneration is in the form of security of supply, the action will be during the window of action established by the program, and the period in which customers must offer the service will be seasonal. It is advisable to make a prior notification in the Daily Market, and a prior notice will be made on the day of the action $(120 \mathrm{~min})$ [68]

\subsubsection{Pennsylvania-New Jersey-Maryland Interconnection LLC (PJM)}

The Pennsylvania-New Jersey-Maryland Interconnection LLC (PJM) manages a total of 13 states with more than 65 million people. It also has an installed generation capacity of $180 \mathrm{GW}$, and the total energy delivered in 2018 was 807 TWh [69]. There are mainly three AS open to DR: Day-Ahead Scheduling Reserve, Synchronized Reserves, and Regulation, in which DRSs can provide up to $25 \%, 33 \%$, and $25 \%$ of the total capacity, respectively [70]. Day-Ahead Scheduling Reserve has the traits of Supplementary Reserve. In all cases, $\Delta \mathrm{P}_{\min }$ is very accessible $(0.1 \mathrm{MW})$, but DRPVs must send information regarding their 
consumption every 1 min [71]. Regarding Synchronized Reserves, DRPVs present bids in a Day-Ahead or in an Intraday market. In 2017, the average DR hourly capacity activated was $110 \mathrm{MW}$, from which $76 \%$ were industrial loads, while the participation of residential loads remained very limited. On the contrary, regulation, which activates as soon as possible, had a remarkable share of residential loads. 79\% of DSRs in this service in 2017 came from water heaters, and 9\% came from batteries. The average DR hourly capacity provided was $10 \mathrm{MW}$.

\subsubsection{Canada-Independent Electricity System Operator (Ontario)}

The Canadian State of Manitoba belongs to MISO's electricity system, so all its programs and market rules apply in this State too. On the other hand, Alberta Electricity System Operator contracted 150 MW of DR in 2011 with Enel X, and now, a new advance on DR development as reserves is being contracted by Enel $\mathrm{X}$ on the basis of 10 to $60 \mathrm{~min}$ contracts with particulars through bids on the day ahead [72]. Apart from Ontario, the rest of the States are still vertically regulated. Independent Electricity System Operator (IESO) launched the first Demand Response auction in 2015. Before that, IESO had secured up $70 \mathrm{MW}$ of DR through a competitive procurement in which bids as small as $1 \mathrm{MW}$ were accepted. The project intended to assess DSRs ability to provide ancillary services. The loads participated in one program [73]. DRPVs commit to curtailing their loads on a day-ahead or four-hours ahead basis, acting like a Supplemental Reserve. IESO manages an annual DR auction in which DRPVs present bids with the capacity they are willing to provide for a defined period. DR offers are expressed in \$/MW month or year, and successful providers will receive a payment according to the capacity awarded and the resulting clearing price [74].

Table 7. Normal FERC programs in North America open to DR: Main parameters.

\begin{tabular}{|c|c|c|c|c|c|}
\hline $\begin{array}{l}\text { Product/Service } \\
\text { (TSO) }\end{array}$ & $\begin{array}{c}\text { Type of } \\
\text { Activation }\end{array}$ & $\mathbf{T}_{\text {RES }}$ & $\Delta \mathbf{P}_{\min }$ & $\mathbf{T}_{\text {MAX }}$ & $\begin{array}{l}\text { Type(s) of } \\
\text { Payment }\end{array}$ \\
\hline $\begin{array}{l}\text { Load Following } \\
\text { (CAISO) }\end{array}$ & Manual & $10 \mathrm{~min}$ & $0.5 \mathrm{MW}$ & $\mathrm{n} / \mathrm{a}$ & Capacity only \\
\hline $\begin{array}{c}\text { Regulating } \\
\text { Reserve (ERCOT) }\end{array}$ & Manual & Immediate & $0.1 \mathrm{MW}$ & $\mathrm{n} / \mathrm{a}$ & Security of supply \\
\hline $\begin{array}{c}\text { Regulating } \\
\text { Reserve (NE-ISO) }\end{array}$ & Automatic & Immediate & $0.1 \mathrm{MW}$ & $\mathrm{n} / \mathrm{a}$ & Capacity only \\
\hline $\begin{array}{c}\text { Regulating } \\
\text { Reserve (MISO) }\end{array}$ & Automatic & $4 \mathrm{~s}$ & $1 \mathrm{MW}$ & $60 \mathrm{~min}$ & $\mathrm{n} / \mathrm{a}$ \\
\hline $\begin{array}{c}\text { Regulating } \\
\text { Reserve (NYISO) }\end{array}$ & Automatic & Immediate & $1 \mathrm{MW}$ & $\mathrm{n} / \mathrm{a}$ & Capacity only \\
\hline $\begin{array}{c}\text { Regulating } \\
\text { Reserve (PJM) }\end{array}$ & Automatic & Immediate & $0.1 \mathrm{MW}$ & $\mathrm{n} / \mathrm{a}$ & $\begin{array}{c}\text { Capacity and } \\
\text { energy }\end{array}$ \\
\hline
\end{tabular}

CAISO: California independent service operator; ERCOT: electric reliability council of Texas; NE-ISO: New England independent service operator; MISO: Midcontinent independent system operator; NYISO: New York independent system operator; PJM: Pennsylvania-New Jersey-Maryland interconnection LLC. 
Table 8. Contingency FERC programs in North America open to DR: Main parameters.

\begin{tabular}{|c|c|c|c|c|c|}
\hline Product/Service (TSO) & $\begin{array}{c}\text { Type of } \\
\text { Activation }\end{array}$ & $\mathbf{T}_{\text {RES }}$ & $\Delta \mathbf{P}_{\min }$ & $\mathrm{T}_{\text {MAX }}$ & $\begin{array}{l}\text { Type(s) of } \\
\text { Payment }\end{array}$ \\
\hline Spinning Reserve (MISO) & Manual & $10 \mathrm{~min}$ & $1 \mathrm{MW}$ & $\mathrm{n} / \mathrm{a}$ & $\mathrm{n} / \mathrm{a}$ \\
\hline Spinning Reserve (NYISO) & Manual & $10 \mathrm{~min}$ & $1 \mathrm{MW}$ & $\mathrm{n} / \mathrm{a}$ & Capacity only \\
\hline Non-Spinning Reserve (ERCOT) & Manual & $10 \mathrm{~min}$ & $0.1 \mathrm{MW}$ & $12 \mathrm{~h}$ & Security of supply \\
\hline Non-Spinning Reserve (ERCOT) & Manual & $10 \mathrm{~min}$ & $0.5 \mathrm{MW}$ & $3 \mathrm{~h}$ & Security of supply \\
\hline Non-Spinning Reserve (ERCOT) & Manual & $10 \mathrm{~min}$ & $0.1 \mathrm{MW}$ & $3 \mathrm{~h}$ & Security of supply \\
\hline Supplemental Reserve (ERCOT) & Manual & $30 \mathrm{~min}$ & $0.1 \mathrm{MW}$ & $12 \mathrm{~h}$ & Security of supply \\
\hline Supplemental Reserve (ERCOT) & Manual & $30 \mathrm{~min}$ & $0.5 \mathrm{MW}$ & $3 \mathrm{~h}$ & Security of supply \\
\hline Supplementary Reserve (MISO) & Manual & $10 \mathrm{~min}$ & $1 \mathrm{MW}$ & $\mathrm{n} / \mathrm{a}$ & $\mathrm{n} / \mathrm{a}$ \\
\hline Supplemental Reserve (NYISO) & Manual & $30 \mathrm{~min}$ & $1 \mathrm{MW}$ & $\mathrm{n} / \mathrm{a}$ & Capacity only \\
\hline Supplemental Reserve (NYISO) & Manual & $2 \mathrm{~h}$ & $0.1 \mathrm{MW}$ & $\mathrm{n} / \mathrm{a}$ & Capacity only \\
\hline Day Ahead Scheduling Reserve (PJM) & Manual & $30 \mathrm{~min}$ & $0.1 \mathrm{MW}$ & $\mathrm{n} / \mathrm{a}$ & $\mathrm{n} / \mathrm{a}$ \\
\hline Synchronized Reserves (PJM) & Manual & $10 \mathrm{~min}$ & $0.1 \mathrm{MW}$ & $30 \mathrm{~min}$ & $\mathrm{n} / \mathrm{a}$ \\
\hline
\end{tabular}

\subsection{Asia and Oceania}

In Asia and Oceania, systems partially allow DR to access AS markets to compete with generation resources. Some TSOs adjusted the technical requirements of these services to match what DRPVs can do. But mostly, TSOs developed special programs only for DSRs, to assure DR participation in front of strong competitors or too demanding technical requirements. At the end of this Section, Table 9 contains the main parameters that characterize Asia and Oceania AS for DR.

\subsubsection{Australia}

Australia has a highly branched and poorly meshed electrical network that suffers from imbalances that dramatically increase prices [75]. One of the measures taken to carry a decentralization of energy production is to invest in flexibility to provide AS, which represents an opportunity to demand [76]. The service that most concerns DR is the Frequency Control AS-, which Australian Energy Market Operator (AEMO) uses to maintain the adequate frequency of the electrical system. There are two types of frequency control in Australia: Regulatory and Contingency. The regulatory control of the frequency presents two programs whose objective is to correct slight drops and rises that may impair the optimal functioning of the system [77]. As for contingency programs, two types exist depending on the ramp of action required by the action, and in FERC's nomenclature, they would be identified as Regulating Reserves and Load Following Services.

\subsubsection{New Zealand}

New Zealand is another country that has been investing in the implantation of renewable energies and monitoring infrastructures [78], and betting progressively on demand flexibility. The first projects were based in the residential sector, which is controlled through monitoring-controlled air conditioning, lighting, and certain household appliances during peak loads [79]. The New Zealand Electricity Authority (NZEA) is the regulatory organization for the country's electricity market and is, in turn, the promoter of different demand-side flexibility pilot projects. NZEA is currently working on defining AS and DR for the country due to the great number of renewable resources installed, which proves great potential for demand flexibility in New Zealand. 


\subsubsection{China}

The State Electricity Regulatory Commission (SERC), together with the National Energy Commission (NEC), oversees promoting and implementing projects that provide greater demand flexibility, thus improving the potential of the electric system. Various demand management programs have been implemented by the Chinese government, which focus on administrative and technical measures. Pilot demand management programs have been carried out in four major cities in the country (Suzhou, Beijing, Foshan, and Tangshan) [80]. These programs require an advanced measurement infrastructure (AMI) to measure baseline and consumption in real time and communication devices to inform users of Smart Demand Response (SDR) activities and analyze their reduction commitment [81]. SDR refers to DR products managed automatically by the country's large telematic infrastructure, which is adapted to the needs, prices, and system circumstances. The two most important SDR programs are the Interruptible Loads program and the Direct Load Control program. Both receive the same economic incentive in exchange for energy reduction. The mentioned programs can compare to FERC Supplemental Reserve Services standards.

\subsubsection{South Korea}

Currently, the effective DR program in Korea is not based on a system of offers but on contracts that decide the incentives, the participation interval, the notification time of the event, etc. However, a bid-based DR program was recently conducted but did not have a major impact [82]. The need for a DSM program is becoming a major problem in Korea and is recognized as a necessary element to solve the demand problem [83]. The load management programs implemented since 2009 in Korea use the regular KPX (Korean Power Exchange) fund bidding system and a voluntary reduction of the summer load, which KEPCO (Korean Electric Power Corporation) coordinates and carries out during the summer holiday period [84]. Coordination of the summer vacation period is used to reduce peak summer demand; its objective is the residential client and the industrial client that surpasses a demand of $100 \mathrm{~kW}\left(\Delta \mathrm{P}_{\min }\right)$ with an economic incentive. The Load Following Service reduces demand during peak summer afternoon hours are targeted to residential, industrial, and educational customers, who receive an economic incentive that is paid in $30 \mathrm{~min}$ rates $\left(\mathrm{T}_{\mathrm{MAX}}\right)$ depending on the power provided. This system contributes to reducing maximum demand, but it will be more difficult to implement since industry labor regularity is more important than the decrease in the price of electricity in an advanced country. Through these satisfactory experiences, South Korea is willing to continue carrying out DR projects and demand flexibility.

\subsubsection{Japan}

The catastrophes that occurred in the country caused the nation to feel threatened by the serious lack of electricity supply. These events sparked the national debate regarding nuclear energy and the approach it should take in the future [85], and one of the measures that were decided to tackle was to encourage the flexibility of the demand for a better insertion of renewable energies. A unique feature of the Japanese approach is the promising role of the business sector, as some of the large Japanese conglomerates such as Toyota, Mitsubishi, Sharp, Toshiba, Fujitsu, Panasonic, NEC Corporation, and Nissan Motors are involved in these projects. Notwithstanding the absence of defined DR programs, due to the massive industry trying to incorporate demand flexibility to their standards, there is great potential for DR in Japan. The main obstacle is found in the massive financing that the deployment of means that the creation of an intelligent network requires; this has been identified as a key barrier for DR [86].

\subsubsection{Singapore}

The Singapore Energy Market Authority (EMA) is responsible for demand easing projects and introduced DR programs to improve competition in the Singapore National Electricity Market (NEMS). Consumers can participate directly or through DR retailers or 
aggregators. The Load Following Service establishes that all customers who can offer a $\Delta \mathrm{P}_{\min }$ of $0.1 \mathrm{MW}$ for half an hour $\left(\mathrm{T}_{\mathrm{MAx}}\right)$ can participate. Consumers participating in the program share a third of the savings from lowering electricity prices as incentive payments, up to the limit on wholesale electricity prices. Registered consumers can temporarily provide the required reduction by turning off non-critical equipment, reducing HVAC or pumping system power, or even using backup generators on-site for short periods.

Table 9. Asian and Oceanian ancillary services open to DR: Main parameters.

\begin{tabular}{cccccc}
\hline Product/Service (Country) & Type of Activation & $\mathbf{T}_{\mathbf{R E S}}$ & $\boldsymbol{\Delta} \mathbf{P}_{\mathbf{m i n}}$ & T $\mathbf{M A X}$ & Type(s) of Payment \\
\hline Regulating Reserve (Australia) & Manual & $60 \mathrm{~s}$ & $0.1 \mathrm{MW}$ & $\mathrm{n} / \mathrm{a}$ & Capacity only \\
\hline Load Following (Australia) & Manual & $5 \mathrm{~min}$ & $0.1 \mathrm{MW}$ & $\mathrm{n} / \mathrm{a}$ & Capacity only \\
\hline Load Following (South Korea) & Manual & $\mathrm{n} / \mathrm{a}$ & $0.1 \mathrm{MW}$ & $30 \mathrm{~min}$ & Capacity only \\
\hline Load Following (Singapore) & Manual & $\mathrm{n} / \mathrm{a}$ & $0.1 \mathrm{MW}$ & 30 min & Capacity only \\
\hline
\end{tabular}

\subsection{Africa and Latin America}

Africa and Latin America are also regions with a great DR potential, but DR programs have not yet been developed. Nevertheless, countries like South Africa are investigating and proving the viability of demand side management and the regulation of electricity demand from the consumer side [87].

\section{Discussion}

As it is proved with the range of DR products from different continents presented in this review, many countries all over the world have developed and keep improving their programs to manage DSRs. DR is one of the elements which are going to characterize electricity markets shortly. A new perspective of decentralized systems, based on Renewable Energy, Distributed Energy Resources, Smart Grids, Virtual Power Plant, and Aggregators, is dominating the debate on how future electricity systems should be, and DR is an essential part of such scenario. The sooner and more efficiently DR is properly implemented in a system's electricity market, the sooner its society will benefit from it, so it is recommendable for all regions to start working on programs like these shortly.

As it is stated in Section 2.1, neighboring countries tend to have similar market designs when it comes to general services. Commonly they even create their nomenclature so that communication between such countries becomes easier and collaboration is more profitable. On the other hand, every TSO has its strategies to face particular issues of its country and, consequently, it designs specific DR products to manage them. For instance, Strategic Reserve in Finland is specially designed to face high winter demands, and Demand Turn $\mathrm{Up}$ in the UK is used in times of low demand and high renewable generation. These services are uncommon in other countries without such issues.

Regarding $\Delta \mathrm{P}_{\min }$ in AS programs open to DR, the most repeated value is $1 \mathrm{MW}$, especially in Europe. Other countries in Asia, America, and Oceania show $\Delta \mathrm{P}_{\min }$ of $0.1 \mathrm{MW}$ in their programs, a more flexible requirement that facilitates DSRs participation on AS. Normally, aggregators can overcome a technical barrier such as this, but with $\Delta \mathrm{P}_{\min }$ of 20 or $25 \mathrm{MW}$ (as found in Europe), even aggregators have difficulties meeting the requirements, and only the largest industrial consumers can access those services.

The search for DR products has revealed a pending global issue: the lack of standardization. TSOs from diverse parts of the world use different terms for similar concepts and design AS in a distinct way. Therefore, it often becomes hard to understand a description of a service from another part of the world. Besides, this fact can make it impossible to apply the same strategy to manage loads in two different countries because technical requirements may not be met in both places. Research shows that countries with standardization, such as European countries or the USA, tend to develop appropriate DR programs more quickly. Nevertheless, even if organizations like ENTSO-E and FERC have worked to 
develop a regional nomenclature accepted by all nearby countries, the standardization must become global to accelerate DR growth all over the world.

Regarding prices for the remuneration of AS provided by DSRs, the prices presented must be considered as an approximation since most of them vary continuously. All energy prices presented refer to upwards activations, that is, a curtailment of load or an increment of generation:

- $\quad$ aFRR or Secondary Reserve. In services classified as aFRR, most of the European TSOs offer availability and an energy payment. Prices for the availability concept are around $18 € / \mathrm{MW} / \mathrm{h}$ (France), $13 € / \mathrm{MW} / \mathrm{h}$ (Finland), $22 € / \mathrm{MW} / \mathrm{h}$ (Switzerland) and even $200 € / \mathrm{MW} / \mathrm{h}$ (the UK). Prices for the energy concept are around 20-40€/MWh (Finland), $70 € / \mathrm{MWh}$ over the spot market price (the Netherlands), and $50 € / \mathrm{MWh}$ (Switzerland).

- $\quad$ mFRR or Tertiary Reserve. TSOs typically pay successful activations of mFRR and similar services with an energy payment only, although there are some exceptions. Prices found for the availability payment are around 5-6€/MW/h (Belgium) and $3 € / \mathrm{MW} / \mathrm{h}$ (Finland). For the energy payment, average prices are around $47 € / \mathrm{MWh}$ (France) and $41 € / \mathrm{MWh}$ (Sweden). In Denmark and The Netherlands, the minimum price is the correspondent spot market price, and in the latter, there is an upper limit of $200 € / \mathrm{MWh}$.

- $\quad \mathrm{RR}$ or Complementary Reserve. As with the mFRR case, most TSOs pay this service with an energy payment only. Typical prices for the availability payment are around $2 € / \mathrm{MW} / \mathrm{h}$ (the UK) and $7 € / \mathrm{MW} / \mathrm{h}$ (Ireland), and for energy, the payment is around $45 € / \mathrm{MWh}$ (France), $73 € / \mathrm{MWh}$ (the UK), $75 € / \mathrm{MWh}$ (Belgium) and between 380-950 €/MWh (Ireland).

Rewards tend to be more generous when the service is more demanding. That explains why aFRR normally has two payments, and mFRR and RR typically only have a utilization payment. Prices are also higher when technical requirements are tougher. Energy payments are especially common in Europe, while most DR services in other continents tend to apply for a capacity payment only. Security of supply is an interesting way to remunerate DR actions, although it would only apply to countries with weak and tricky networks, being an insufficient reward otherwise.

DR's success and participation on AS are more common in services with high $T_{R E S}$, such as mFRR and equivalents, but consumers are getting involved in FCR and aFRR gently. In the USA most of the services characterized are equivalent to the spinning reserve, but there are also many products designed to be triggered immediately, probably due to the earlier use of DSRs to provide AS.

DR's success is dependent on several factors, such as load traits (residential, industrial, and commercial), the share of renewables in a country's electricity system, or generator competition. A key aspect results from the inclusion of residential consumers in DR programs, which are currently excluded from many markets such as Belgium. This will result from the integration and massification of aggregation services as a key element to untap the residential flexibility as it occurs in most USA systems and South Korea.

To improve the possibility of DR prosperity, all these factors must be analyzed before the design of products, and the conclusions of such analysis must be considered when establishing technical requirements and new market rules. Still, experience proves that some aspects are essential for a prosperous DR progress, such as low $\Delta \mathrm{P}_{\min }$, and the acknowledgment of independent aggregators. Moreover, products' impact on market efficiency and DR development must be tracked to introduce the changes needed.

\section{Conclusions}

To conclude, DR proves to be a valuable resource to ensure the security of supply while reducing demand peaks, avoid blackouts, reduce investments on the grid, and absorb renewable fluctuations. To do so, programs to allow and enhance the participation of DR in AS have been occurring throughout the globe. Many countries aim to mobilize their 
demand resources to provide reserves and directly compete with generation in AS markets. DR usage is still scarce, and, in most countries, its deployment is low or inexistent due to inexistent regulation, technical parameters drafted for generators, and lack of experience. Even though most countries follow regional grid standards, where DR programs for AS exist, these do not follow common parameters and lack standardization due to the different parameters involved as a DRPV. In this regard, no analysis or comparison appears in the literature of the different parameters and prices of DRP in AS among different countries.

The contribution of this work is to provide an academic, precise, and concise analysis of the different country programs under a framework of standardized parameters of both AS and DRP. First, the paper has defined the grid standards developed by ENTSO-E and the FERC, the AS associated with them, and their main technical characteristics. Second, we have presented the DRP existing in the different countries and systems around the world that have incorporated DRP in their AS. The programs are presented systematically with their main characteristics such as the minimum response time, the type of payment and activation form, minimum and maximum times, minimum power required to participate, and if aggregation is allowed or not. Third, a review of the average and most common prices and forms of payment and the main policy conclusions around the programs are presented. Our work shows how countries with wider participation have lower minimum power levels and allow aggregation. It is important to note that higher penetrations of renewables, the electrification of demand, and more extreme climate conditions associated with the effects of climate change will impose extra needs on the system, to which DR results in a valuable resource to help to balance it.

Author Contributions: Conceptualization, D.R.-P. and M.A.-O., methodology, D.R.-P., L.L.-L. and M.A.-O.; formal analysis, D.R.-P., L.L.-L., and D.P.-T.; resources, M.A.-O.; data curation, L.L.-L. and D.P.-T.; writing—original draft preparation, D.R.-P., L.L.-L. and D.P.-T.; writing—review and editing, D.R.-P. and M.A.-O.; supervision, M.A.-O.; project administration, M.A.-O.; funding acquisition, M.A.-O. All authors have read and agreed to the published version of the manuscript.

Funding: This work was funded by the Fundación Iberdrola and in part by the Spanish public administration under grant FPU2016/00962.

Institutional Review Board Statement: Not applicable.

Informed Consent Statement: Not applicable.

Data Availability Statement: Data is contained within the article.

Conflicts of Interest: The authors declare no conflict of interest.

\author{
Abbreviations \\ aFRR Frequency Restoration Reserves with Automatic Activation \\ AGC Automatic Generation Control \\ AS Ancillary Services \\ BSP Balance Service Providers \\ CAISO California Independent System Operator \\ DEG Distributed Energy Generation \\ DER Distributed Energy Resources \\ DR Demand Response \\ DRPV Demand Response Provider \\ DRRQ Demand Response Requester \\ DSR Demand Side Resources \\ DSM Demand Side Management \\ ENTSO-E European Network of Transmission System Operators for Electricity \\ ERCOT Electric Reliability Council of Texas \\ FCR Frequency Containment Reserve \\ FERC Federal Energy Regulatory Commission
}


FRR Frequency Restoration Reserve

ICT Information and Communication Technologies

ISO Independent System Operator (in USA)

mFRR Frequency Restoration Reserves with Manual Activation

MISO Midcontinent Independent System Operator

NE-ISO New England Independent System Operator

NYISO New York Independent System Operator

PJM Pennsylvania-New Jersey-Maryland Interconnection LLC

RR Replacement Reserve

RTO Regional Transmission Organization (in USA)

SO System Operator

STOR Short-Term Operating Reserve

TSO Transmission System Operator

$\Delta \mathrm{P}_{\min } \quad$ Minimum capacity that needs to be demonstrated by a BSP to access a specific ancillary service

$\mathrm{T}_{\mathrm{MAX}} \quad$ Maximum length of a DR action

$\mathrm{T}_{\mathrm{RES}} \quad$ Maximum admissible time between a TSO's notification and a BSP's full activation

$\mathrm{T}_{\mathrm{RAM}} \quad$ Maximum duration for a BSP to adapt its power curve to the given setpoint, from the start of the modification

$\mathrm{T}_{\mathrm{RAM}, \mathrm{RD}}$ Time used by a DRV to adapt its power curve to the given setpoint, from the start of the modification

$\mathrm{T}_{\mathrm{MAX} \text {,RD }}$ Maximum duration of a DRPV's activation

$\mathrm{T}_{\mathrm{RCT}} \quad$ Total time that a DRPV needs to achieve the givenr setpoint, from the arrival of the TSO's notification

$\triangle \mathrm{P}_{\mathrm{R} 1} \quad$ Flexible power of a DRPV

$\Delta \mathrm{P}_{\mathrm{R} 2} \quad$ Extra power consumed before the DR action by the DRPV

$\Delta \mathrm{P}_{\mathrm{R} 3} \quad$ Extra power consumed after the DR action by the DRPV

$T_{\text {PRE }} \quad$ Duration of the preparation for a DR action needed by the DRPV

$\mathrm{T}_{\mathrm{REC}} \quad$ Duration of the recovery from a DR action needed the DRPV

\section{References}

1. IPCC. Summary for Policymakers-Global Warming of $1.5^{\circ}$ C. 2018. Available online: https://www.ipcc.ch/sr15/chapter/spm/ (accessed on 1 April 2020).

2. Huber, M.; Dimkova, D.; Hamacher, T. Integration of wind and solar power in Europe: Assessment of flexibility requirements. Energy 2014, 69, 236-246. [CrossRef]

3. Schleicher-Tappeser, R. How renewables will change electricity markets in the next five years. Energy Policy 2012. [CrossRef]

4. Helm, D. Burn Out: The Endgame for Fossil Fuels; Yale University Press: London, UK, 2017.

5. Callaway, D.S.; Hiskens, I.A. Achieving controllability of electric loads. Proc. IEEE 2011. [CrossRef]

6. Li, J.B.; Wang Shen, X.; Jiang, C. From controllable loads to generalized demand-side resources: A review on developments of demand-side resources. Renew. Sustain. Energy Rev. 2016. [CrossRef]

7. Palensky, P.; Dietrich, D. Demand side management: Demand response, intelligent energy systems, and smart loads. IEEE Trans. Ind. Inform. 2011. [CrossRef]

8. Alcázar-Ortega, M.; Álvarez-Bel, C.; Escrivá-Escrivá, G.; Domijan, A. Evaluation and assessment of demand response potential applied to the meat industry. Appl. Energy 2012, 92, 84-91. [CrossRef]

9. Burger, S.P.; Jenkins, J.D.; Huntington, S.C.; Perez-Arriaga, I.J. Why distributed?: A critical review of the tradeoffs between centralized and decentralized resources. IEEE Power Energy Mag. 2019, 17, 16-24. [CrossRef]

10. Jazayeri, P.; Schellenberg, A.; Rosehart, W.D.; Doudna, J.A.D.J.; Widergren, S.A.W.S.; Lawrence, D.; Mickey, J.A.M.J.; Jones, S.A.J.S. A survey of load control programs for price and system stability. IEEE Trans. Power Syst. 2005. [CrossRef]

11. Rodríguez-García, J.; Ribó-Pérez, D.; Álvarez-Bel, C.; Peñalvo-López, E. Novel conceptual architecture for the next-generation electricity markets to enhance a large penetration of renewable energy. Energies 2019, 12. [CrossRef]

12. Gellings, C.W. The Smart Grid: Enabling Energy Efficiency and Demand Response-Clark W. Gellings-Google Libros; The Fairmont Press Inc.: Lilburn, GA, USA, 2009.

13. Borlase, S. Smart Grids Infrastructure, Technology and Solutions, 1st ed.; CRC Press: Boca Raton, FL, USA, 2013.

14. Albadi, M.H.; El-Saadany, E.F. A summary of demand response in electricity markets. Electr. Power Syst. Res. 2008. [CrossRef]

15. Wang, Q.; Zhang, C.; Ding, Y.; Xydis, G.; Wang, J.; Østergaard, J. Review of Real-Time Electricity Markets for Integrating Distributed Energy Resources and Demand Response; Elsevier: Amsterdam, The Netherlands, 2015; Volume 138, pp. 695-706.

16. Boßmann, T.; Eser, E.J. Model-based assessment of demand-response measures-A comprehensive literature review. Renew. Sustain. Energy Rev. 2016. [CrossRef]

17. Siano, P. Demand response and smart grids-A survey. Renew. Sustain. Energy Rev. 2014. [CrossRef]

18. Rodriguez-Garcia, J.; Ribo-Perez, D.; Alvarez-Bel, C.; Penalvo-Lopez, E. Maximizing the profit for industrial customers of providing operation services in electric power systems via a parallel particle swarm optimization algorithm. IEEE Access 2020, 8, 24721-24733. [CrossRef] 
19. Burger, S.P.; Luke, M. Business models for distributed energy resources: A review and empirical analysis. Energy Policy 2017. [CrossRef]

20. Babar, M.; Nyugen, P.H.; Cuk, V.; Kamphuis, I.G.R.; Bongaerts, M.; Hanzelka, Z. The rise of AGILE demand response: Enabler and foundation for change. Renew. Sustain. Energy Rev. 2016. [CrossRef]

21. Oconnell, N.; Pinson, P.; Madsen, H.; Omalley, M. Benefits and challenges of electrical demand response: A critical review,". Renew. Sustain. Energy Rev. 2014. [CrossRef]

22. Ribó-Pérez, D.; van der Weijde, A.H.; Álvarez-Bel, C. Effects of self-generation in imperfectly competitive electricity markets: The case of Spain. Energy Policy 2019, 133, 110920. [CrossRef]

23. European Comission. Directive (EU) 2019/944 on Common Rules for the Internal Market for Electricity. 2019. Available online: https:/ / eur-lex.europa.eu/legal-content/EN/TXT/PDF/?uri=CELEX:32019L0944\&from=EN (accessed on 14 October 2019).

24. Burger, S.; Chaves-Ávila, J.P.; Batlle, C.; Pérez-Arriaga, I.J. A review of the value of aggregators in electricity systems. Renew. Sustain. Energy Rev. 2017, 77, 395-405. [CrossRef]

25. Ikäheimo, J.; Evens, C.; Kärkkäinen, S. DER Aggregator Business: The Finnish Case. 2010. Available online: http://www.ece.hut. fi/enete/DER_Aggregator_Business_Finnish_Case.pdf (accessed on 18 February 2019).

26. Lopes, J.A.P.; Hatziargyriou, N.; Mutale, J.; Djapic, P.; Jenkins, N. Integrating distributed generation into electric power systems: A review of drivers, challenges and opportunities. Electr. Power Syst. Res. 2007. [CrossRef]

27. ENTSO-E. An Overview of the European Balancing Market and Electricity Balancing Guideline. 2018. Available online: https: / / www.entsoe.eu/about/ (accessed on 24 August 2020).

28. FERC. What FERC Does Federal Energy Regulatory Commission. 2020. Available online: https://www.ferc.gov/about/whatferc/what-ferc-does (accessed on 30 July 2020).

29. NERC Essential Reliability Services Task Force. 2014. Available online: https:/ /www.nerc.com/comm/Other/essntlrlbltysrvcstskfrcDL/ ERSTF\%20Framework\%20Report\%20-\%20Final.pdf (accessed on 17 July 2020).

30. ENERNOC. The Demand Response Baseline. 2009. Available online: https://www.naesb.org/pdf4/dsmee_group3_100809w3 .pdf (accessed on 24 August 2020).

31. Alcázar-Ortega, M.; Calpe, C.; Theisen, T.; Rodríguez-García, J. Certification prerequisites for activities related to the trading of demand response resources. Energy 2015. [CrossRef]

32. SEDC. Explicit Demand Response in Europe Mapping the Markets 2017 Smart Energy Demand Coalition. 2017. Available online: www.smartenergydemand.eu (accessed on 4 October 2018).

33. Hurley, D.; Peterson, P.; Whited, M. Demand Response as a Power System Resource Program Designs, Performance, and Lessons Learned in the United States. 2013. Available online: www.raponline.org (accessed on 24 August 2020).

34. ISO/RTO Council. North American Wholesale Electricity Demand Response Program Comparison. 2018. Available online: https: / / isorto.org/wp-content/uploads/2018/12/2018-Demand-Response-Program-Comparison.xlsx (accessed on 13 May 2020).

35. Frost\&Sullivan. Is the Asia-Pacific Region Demand Response Ready? 2018. Available online: https://ww2.frost.com/frostperspectives / asia-pacific-region-demand-response-ready / (accessed on 30 July 2020).

36. Fingrid. Demand-Side Management_Fingrid. 2020. Available online: https://www.fingrid.fi/en/electricity-market/marketintegration/the-future-of-the-electricity-markets/demand-side-management/ (accessed on 24 August 2020).

37. Honkapuro, S.; Tuunanen, J.; Valtonen, P.; Partanen, J.; Järventausta, P.; Heljo, J.; Harsia, P. Practical implementation of demand response in Finland. In Proceedings of the 23rd International Conference and Exhibition on Electricity Distribution-CIRED, Lyon, France, 15-18 June 2015.

38. Fingrid. Reserve Products and Reserve Market Places. 2020. Available online: https://www.fingrid.fi/en/electricity-market/ reserves_and_balancing/(accessed on 27 May 2020).

39. RTE. Electricity Report 2018. 2019. Available online: https://bilan-electrique-2018.rte-france.com/wp-content/uploads/2019/0 2/BE-PDF-2018-1.pdf (accessed on 25 March 2020).

40. Bailey, I.; Revell, P. Potentiale regelbarer Lasten in einem Energieversorgungs- system mit wachsendem Anteil erneuerbarer Energien. Int. Encycl. Soc. Behav. Sci. Second Ed. 2015. [CrossRef]

41. Stede, J. Demand response in Germany: Technical potential, benefits and regulatory challenges. DIW Roundup 2016, 96.

42. Gils, H.C. Economic potential for future demand response in Germany-Modeling approach and case study. Appl. Energy 2016. [CrossRef]

43. Regelleistung. Common Tendering Secondary Control Reserve. 2020. Available online: https://www.regelleistung.net/ext/ static/srl?lang=en (accessed on 24 August 2020).

44. EIRGRID. Electricity Transmission Performance Report 2017. 2018. Available online: http:/ /www.eirgridgroup.com/site-files/ library/EirGrid/201553-Eirgrid-TSO-and-TAO-Report_LR5.pdf (accessed on 24 August 2020).

45. TENNET. Product Information Automatic Frequency Restoration Reserve. 2020. Available online: https://www.tennet.eu/ fileadmin/user_upload/SO_NL/Product_information_aFRR.pdf (accessed on 23 February 2020).

46. Panos, E.; Kober, T.; Wokaun, A. Long term evaluation of electric storage technologies vs alternative flexibility options for the Swiss energy system. Appl. Energy 2019, 252, 113470. [CrossRef]

47. Swedish Energy Markets Inspectorate Measures to Increase Demand Side Flexibility in the Swedish Electricity System Abbreviated Version. 2017. Available online: www.ei.se (accessed on 31 January 2021).

48. Swissgrid. Basic Principles of Ancillary Service Products. 2019. Available online: www.swissgrid.ch (accessed on 24 August 2020). 
49. National Grid. Short Term Operating Reserve. General Description of the Service. 2017. Available online: https://www.nationalgrid. com/sites/default/files/documents/STOR\%20Standard\%20Contract $\% 20$ Terms $\% 20$ Issue $\% 2010 \% 20 \% 28$ Effective $\% 20$ from $\% 20$ 1\%20April\%202017\%29\%20\%281\%29_0.pdf (accessed on 28 March 2020).

50. National Grid. Fast Reserve. 2020. Available online: https://www.nationalgrideso.com/industry-information/balancingservices/reserve-services/fast-reserve (accessed on 24 August 2020).

51. National Grid. Fast Reserve Tender Report Dec-19. 2019. Available online: https://data.nationalgrideso.com/ancillary-services/ fast-reserve-tender-reports/r/fast_reserve_tender_report_dec-19 (accessed on 24 August 2020).

52. CAISO. Overview of Reliability Demand Response Resource. 2014. Available online: http://www.caiso.com/Documents/ ReliabilityDemandResponseResourceOverview.pdf (accessed on 30 July 2020).

53. CAISO. Proxy Demand Resource (PDR) \& Reliability Demand Response Resource (RDRR) Participation Overview. 2020. Available online: http:/ / www.caiso.com/Documents/PDR_RDRRParticipationOverviewPresentation.pdf (accessed on 30 July 2020).

54. Mathieu, J.L.; Dyson, M.E.H.; Callaway, D.S. Resource and revenue potential of California residential load participation in ancillary services. Energy Policy 2015. [CrossRef]

55. Rochlin, C. The Alchemy of demand response: Turning demand into supply. Electr. J. 2009. [CrossRef]

56. Bayer, B. Current practice and thinking with integrating demand response for power system flexibility in the electricity markets in the USA and Germany. Curr. Sustain. Energy Rep. 2015. [CrossRef]

57. Patterson, M. Demand Response in the ERCOT Markets. 2011. Available online: https://pdfs.semanticscholar.org/2b81/d7e158 bb8a79fcdc833ffcea8484072e3f17.pdf (accessed on 12 May 2020).

58. Liu, M.; Lee, W.J.; Lee, L.K. Financial opportunities by implementing renewable sources and storage devices for households under ERCOT demand response programs design. IEEE Trans. Ind. Appl. 2014. [CrossRef]

59. ERCOT. Annual Report of Demand Response in the ERCOT Region. 2017. Available online: http://www.ercot.com/content/ wcm/lists/94805/2017_Annual_Report_of_Demand_Response_in_the_ERCOT_Region.docx (accessed on 12 May 2020).

60. Aalami, H.A.; Moghaddam, M.P.; Yousefi, G.R. Demand response modeling considering Interruptible/Curtailable loads and capacity market programs. Appl. Energy 2010. [CrossRef]

61. Paterakis, N.G.; Erdinç, O.; Catalão, J.P.S. An overview of demand response: Key-elements and international experience. Renew. Sustain. Energy Rev. 2017, 69, 871-891. [CrossRef]

62. Burke, R.B.; Henderson, M.I. Incorporating Demand Response in Operating Reserve in New England. IEEE Power Eng. Soc. Gen. Meet. 2005. [CrossRef]

63. Cappers, P.; MacDonald, J.; Goldman, C.; Ma, O. An assessment of market and policy barriers for demand response providing ancillary services in U.S. electricity markets. Energy Policy 2013, 62, 1031-1039. [CrossRef]

64. MISO. About MISO. 2020. Available online: https:/ / www.misoenergy.org/about/ (accessed on 24 August 2020).

65. MISO. BPM 002-Energy and Operating Reserve Markets. Available online: https://www.misoenergy.org/legal/businesspractice-manuals/ (accessed on 24 August 2020).

66. MISO. Demand Response-FAQs. 2020. Available online: https://www.misoenergy.org/stakeholder-engagement/issuetracking/update-to-demand-response-deployment-tools / (accessed on 18 May 2020).

67. Walawalkar, R.; Fernands, S.; Thakur, N.; Chevva, K.R. Evolution and current status of demand response (DR) in electricity markets: Insights from PJM and NYISO. Energy 2010. [CrossRef]

68. NYISO Manual 7 Emergency Demand Response Program Manual. 2020. Available online: www.nyiso.com (accessed on 24 August 2020).

69. PJM. 2019 PJM Annual Report. 2019. Available online: https://www.pjm.com/-/media/about-pjm/newsroom/annual-reports/ 2019-annual-report.ashx?la=en (accessed on 24 August 2020).

70. PJM. Demand Response (and PRD) Opportunities in PJM Wholesale Markets Emergency Energy Only. 2017. Available online: www.pjm.com (accessed on 24 August 2020).

71. PJM. PJM Demand Side Response Overview. 2014. Available online: https://www.pjm.com/ \{\}/media/training/pjm-demandside-response-overview-v2.ashx (accessed on 23 May 2020).

72. Enel, X. Earn payments for supporting the grid. Everything You Need to Know About the Alberta Operating Reserves Program. 2020. Available online: https://www.enelx.com/n-a/en/faq/eindustry/aeso-operating-reserves-program (accessed on 10 June 2020).

73. IESO. Demand Response Pilot. 2020. Available online: http://www.ieso.ca/en/Sector-Participants/Market-Operations/Marketsand-Related-Programs/Demand-Response-Pilot (accessed on 24 August 2020).

74. IESO. Markets and Related Programs. 2020. Available online: https://www.ieso.ca/en/Sector-Participants/Market-Operations/ Markets-and-Related-Programs / Real-time-Energy-Market (accessed on 22 June 2020).

75. Li, H.X.; Edwards, D.J.; Hosseini, M.R.; Costin, G.P. A review on renewable energy transition in Australia: An updated depiction. J. Clean. Prod. 2020. [CrossRef]

76. AEMO. Market Ancillary Service Specification v5.0. 2017. Available online: www.aemo.com.au (accessed on 24 August 2020).

77. AEMC. International Review of Demand Response Mechanisms. 2015. Available online: https://www.aemc.gov.au/sites/ default/files / content/9207cd67-c244-46eb-9af4-9885822cefbe/Final-AEMC-DR-Report_International-Review-of-DemandResponse-Mechanisms.pdf (accessed on 15 June 2020). 
78. Gyamfi, S. Pattern recognition residential demand response: An option for critical peak demand reduction in New Zealand. In Proceedings of the 4th International Conference on Sustainable Development, Dhaka, Bangladesh, 18-19 February 2010.

79. Chakrabarti, B.; Bullen, D.; Edwards, C.; Callaghan, C. Demand response in the New Zealand Electricity market. PES TED 2012. [CrossRef]

80. Stern, F. Demand Response in China. The Market \& Strategic Positioning of Active Players. 2015. Available online: www.azureinternational.com (accessed on 24 August 2020).

81. Guo, P.; Li, V.O.K.; Lam, J.C.K. Smart demand response in China: Challenges and drivers. Energy Policy 2017. [CrossRef]

82. Lee, S.S.; Ahn, S.H.; Park, J.H.; Heo, J.H.; Kim, D.H.; Park, J.K.; Yang, M.U.; Kim, K.J.; Yoon, Y.T. South Korean power distribution system-based operation, market structure and regulation strategies under distributed generation and smart grid. IEEE Power Energy Soc. Gen. Meet. 2012. [CrossRef]

83. Lee, S.S.; Lee, H.C.; Yoo, T.H.; Noh, J.W.; Na, Y.J.; Park, J.K.; Yoon, Y.T. Demand response prospects in the South Korean power system. IEEE PES Gen. Meet. 2010. [CrossRef]

84. Lee, S.S.; Yoon, Y.T.; Moon, S.I.; Park, J.K. Smart grid based nuclear load-following operation strategies in the South Korean power system. IEEE Power Energy Soc. Gen. Meet. 2013. [CrossRef]

85. Shrader-Frechette, K. Nuclear catastrophe, disaster-related environmental injustice, and Fukushima, Japan: Prima-facie evidence for a Japanese 'katrina'. Environ. Justice 2012. [CrossRef]

86. Nakada, T.; Shin, K.; Managi, S. The effect of demand response on purchase intention of distributed generation: Evidence from Japan. Energy Policy 2016. [CrossRef]

87. CMonyei, G.; Adewumi, A.O. Integration of demand side and supply side energy management resources for optimal scheduling of demand response loads-South Africa in focus. Electr. Power Syst. Res. 2018. [CrossRef] 